\title{
Soil organic matter influences cerium translocation and physiological processes in kidney bean plants exposed to cerium oxide nanoparticles
}

Sanghamitra Majumdar ${ }^{\dagger}$, Jose R. Peralta-Videa ${ }^{\dagger \uparrow}$, Jesica Trujillo-Reyes ${ }^{\dagger}$, Youping Sun ${ }^{\S}$, Ana C. Barrios ${ }^{\dagger}$, Genhua Niu ${ }^{\S}$, Juan P. Flores- Margez ${ }^{\phi}$, Jorge L. Gardea-Torresdey ${ }^{*}+\uparrow:$

'Department of Chemistry, The University of Texas at El Paso, 500 West University Ave., El Paso, TX 79968, USA

${ }^{\top}$ Environmental Science and Engineering PhD Program, The University of Texas at El Paso, 500 West University Ave., El Paso, TX 79968, USA

${ }^{\ddagger}$ University of California Center for Environmental Implications of Nanotechnology (UC CEIN), El Paso, Texas, USA

${ }^{\S}$ Texas AgriLife Research Center at El Paso, Texas A\&M University System, 1380 A \& M Circle, El Paso, Texas 79927, USA

${ }^{\Phi}$ Autonomous University of Ciudad Juarez, Departamento de Química y Biología, Instituto de Ciencias Biomédicas, Anillo envolvente PRONAF y Estocolmo, Ciudad Juarez, Chihuahua 32310, México

*Corresponding author: jgardea@utep.edu, Phone: 915-747-5359; Fax: 915-747-5748 


\begin{abstract}
Soil organic matter plays a major role in determining the fate of the engineered nanomaterials (ENMs) in the soil matrix and effects on the residing plants. In this study, kidney bean plants were grown in soils varying in organic matter content and amended with $0-500 \mathrm{mg} / \mathrm{kg}$ cerium oxide nanoparticles (nano- $\mathrm{CeO}_{2}$ ) under greenhouse condition. After 52 days of exposure, cerium accumulation in tissues, plant growth and physiological parameters including photosynthetic pigments (chlorophylls and carotenoids), net photosynthesis rate, transpiration rate, and stomatal conductance were recorded. Additionally, catalase and ascorbate peroxidase activities were measured to evaluate oxidative stress in the tissues. The translocation factor of Ce in the nano$\mathrm{CeO}_{2}$ exposed plants grown in organic matter enriched soil (OMES) was twice as the plants grown in low organic matter soil (LOMS). Although the leaf cover area increased by $65-111 \%$ with increasing nano- $\mathrm{CeO}_{2}$ concentration in LOMS, the effect on the physiological processes were inconsequential. In OMES leaves, exposure to $62.5-250 \mathrm{mg} / \mathrm{kg}$ nano- $\mathrm{CeO}_{2}$ led to an enhancement in the transpiration rate and stomatal conductance, but to a simultaneous decrease in carotenoid contents by $25-28 \%$. Chlorophyll $a$ in the OMES leaves also decreased by 27 and $18 \%$ on exposure to 125 and $250 \mathrm{mg} / \mathrm{kg}$ nano- $\mathrm{CeO}_{2}$. In addition, catalase activity increased in LOMS stems, and ascorbate peroxidase increased in OMES leaves of nano- $\mathrm{CeO}_{2}$ exposed plants, with respect to control. Thus, this study provides clear evidence that the properties of the complex soil matrix play decisive roles in determining the fate, bioavailability, and biological transport of ENMs in the environment.
\end{abstract}

Keywords: Soil organic matter, cerium oxide nanoparticles, kidney bean, gas exchange, photosynthetic pigments, phytotoxicity 


\section{Introduction}

Along with the vast array of applications that the various classes of engineered nanomaterials (ENMs) offer, they are associated with unknown risks throughout their life cycle in different environmental conditions. The fate of ENMs in the environment depends on their physicochemical properties (like composition, particle size, surface charge, and dissolution) as well as the nature of the target environmental matrices (Cornelis et al., 2014; Peijnenburg et al., 2015). In addition, modulating the ENM properties for various biological applications such as medicine (Nguyen and Zhao, 2015) and agriculture (Kah et al., 2013), also makes them bioavailable to other non-targeted species, as they likely transport and distribute across different media (Liu and Cohen, 2014). This poses serious challenges towards a precise hazard and risk assessment of ENMs to aid regulatory measures and decision-making.

Recent computational modelling and simulation studies on the environmental fate of ENMs involving mass flow and multimedia apportionment have estimated that the major fraction of the released ENMs during production, usage, and disposal, finally accumulate in soils or sediments (Collin et al., 2014; Liu and Cohen, 2014; Keller and Lazareva 2014). This raises concerns due to the possibility of transport of the ENMs from the soils to agricultural crops and, eventually, bioaccumulation in the food chain (Judy et al., 2011; Gardea-Torresdey et al., 2014; Hawthorne et al., 2014; Majumdar et al., 2015), or leaching to the groundwater (Quik et al., 2010). Soil properties including texture, porosity, $\mathrm{pH}$, ionic strength, organic matter, and mineral composition play a pivotal role in determining the aggregation, dissolution, chemical transformation, bioavailability, and migration of ENMs in the porous media, as well as in their interactions at the nano-bio interface (Schwabe et al., 2013; Cornelis et al., 2014; Garner and Keller, 2014; Read et al., 2015; Conway and Keller, 2016). Soil organic matter (SOM) is 
primarily (60-80\%) composed of humic acids, fulvic acids, and humin, which are direct products of plant residue decomposition (Brady and Weil, 2008). Evidences show that organic acids like humic and fulvic acids stabilize several metal oxide nanoparticles in aqueous solutions, including nano- $\mathrm{CeO}_{2}$ (Yang et al., 2009; Schwabe et al., 2013), zinc oxide (nano-ZnO) (Zhang et al., 2009), and titanium oxide (nano- $\mathrm{TiO}_{2}$ ) ( $\mathrm{Zhang}$ et al., 2009; Domingos et al., 2009), owing to enhanced charge and/or steric stabilization (Quik et al., 2010). This prevents aggregation of ENMs, possibly leading to their stability and prolonged suspension in the soil pore water or increased mobility through plant roots. Johnson et al. (2009) demonstrated enhanced mobility of nano-zero valent iron (nZVI) in granular media in the presence of natural organic matter.

Due to increasing potential applications of nano- $\mathrm{CeO}_{2}$ in electronics, catalysis, fuel additives, agriculture, and medicine (Collin et al., 2014), recent phytotoxicity studies are more focused on realistic exposure conditions (Holden et al., 2016). Consolidation of several soilbased studies with nano- $\mathrm{CeO}_{2}$ may reach to a consensus that although, it is actively transported within plants, it is less detrimental in terms of effects on growth and metabolic processes compared to other metal oxide nanoparticles (Wang et al., 2012; Priester et al., 2012; Zhao et al. 2013, 2015). However, negative effects have been also reported on nitrogen fixation in soybeans (Priester et al., 2012), crop yield in corn, cucumber and soybeans (Zhao et al. 2013, 2015; Priester et al., 2012), and also on the nutritional quality of the edible seeds in different plants like rice (Rico et al., 2013) and kidney beans (Majumdar et al., 2015). Surprisingly, filial generations of Brassica rapa plants were shown to experience higher oxidative stress compared to parent plants (Ma et al., 2016). Although the literature on the fate and toxicity of nano- $\mathrm{CeO}_{2}$ keeps on growing exponentially, there have been very few investigations directly addressing the role of SOM in the nano-plant interactions under natural conditions. Schwabe et al. (2013) reported that 
supplemented organic matter enhanced root adsorption of Ce in pumpkin and wheat plants exposed to $100 \mathrm{mg} / \mathrm{L}$ nano- $\mathrm{CeO}_{2}$ suspended in Hoagland culture medium. In corn plants, lower Ce translocation to aerial tissues was observed in organic matter rich soil, compared to natural unenriched soil amended with bare as well as alginate-coated nano- $\mathrm{CeO}_{2}$ (Zhao et al., 2012). According to Zhang et al. (2016), silty loam soil with lower SOM content ( $2 \%)$ had more exchangeable/bioavailable fraction of $\mathrm{Ce}$, leading to higher translocation to radish shoots, compared to loamy sand soil $(\sim 12 \%)$. This suggests that soil components have a high potential to modulate the surface properties of ENMs. This modulation can change the transport within plants and the effects of ENMs in plant health and metabolic processes. Extensive research is needed in order to fully understand these phenomena.

To the best of the authors' knowledge, there are no existing reports investigating SOM dependent toxicological response in plants exposed to nano- $\mathrm{CeO}_{2}$. In this study, we examined the effect of nano- $\mathrm{CeO}_{2}$ at varying concentrations on physicochemical properties of the soils and the effects on kidney bean plants grown for 52 days from germination. The Ce uptake by roots and further translocation to aerial parts were analyzed using inductively coupled plasma-optical emission spectroscopy. We examined varying SOM content as a factor of the changes in various physiological markers like net photosynthesis, stomatal conductance, transpiration, and leaf area. Additionally, photosynthetic pigments and the activities of antioxidant enzymes in different tissues were assessed to investigate stress response in the plants.

\section{Materials and methods}

\subsection{Cerium oxide nanomaterials}


The nano- $\mathrm{CeO}_{2}$ particles ( $\sim 8 \mathrm{~nm}$, Meliorum Technologies, Rochester, NY) were procured from The University of California Center for Environmental Implications of Nanotechnology (UC-CEIN). Keller et al. (2010) characterized these nanoparticles as 100\% cubic ceria nanorods (95.14\% pure), measuring $(67 \pm 8) \mathrm{nm} \times(8 \pm 1) \mathrm{nm},(\leq 10 \%$ polyhedral; $8 \pm 1 \mathrm{~nm})$ with a

surface area of $93.8 \mathrm{~m} \mathrm{~g}^{2}$. . Suspensions of nano- $\mathrm{CeO}_{2}$ in Millipore water (MPW) were prepared using 30 min bath sonication and characterized for size and zeta potential using Zetasizer Nano ZS90 (Malvern Instruments, Worcestershire, U.K.). The measurements were done in triplicates, each with three consecutive readings for technical replication.

\subsection{Soil collection and preparation}

Natural soil was collected from an agricultural field in Fabens, TX (N 31 $29^{\prime}$ 02.1', W $106^{\circ} 08^{\prime} 27.2^{\prime \prime}$, elevation 1102 meters, mineral horizon, depth $55 \mathrm{~cm}$ ). The soil was classified as sandy loam soil (64\% sand, $31 \%$ silt, $5 \%$ clay) according to USDA soil texture classification. Half portion of the collected soil was amended with Miracle-Gro potting mix at 2:1 (v/v) ratio to enhance the SOM content. Based on comparative soil organic matter (SOM) content (Majumdar et al., 2015), the collected natural soil (4.2\%) was called low organic matter soil (LOMS) and the potting mix added soil (10.1\%) was called organic matter enriched soil (OMES). According to Majumdar et al. (2015), soil characteristics including pH, electrical conductivity (EC), total dissolved solid (TDS), and cation exchange capacity (CEC) of LOMS were 7.9 $\pm 0.1,208 \pm 4.8$ $\mu \mathrm{S} / \mathrm{cm}, 23.3 \pm 1.8 \mathrm{meq} / 100 \mathrm{~g}$ and $92.5 \pm 2.5 \mathrm{mg} / \mathrm{L}$, respectively; and of OMES were $7.3 \pm 0.1$, $485 \pm 35.7 \mu \mathrm{S} / \mathrm{cm}, 33.1 \pm 1.3 \mathrm{meq} / 100 \mathrm{~g}$ and $240 \pm 19.2 \mathrm{mg} / \mathrm{L}$. Soil bulk density was measured following McKenzie et al. (2004). Water holding capacity (\%) of the soils were also calculated to estimate the total volume of the applied nanosuspensions, as follows: [\{Mass of water to saturate the soil (g)/Oven dry weight of the soil (g)\} x100]. The water holding capacity for 
LOMS and OMES was 17 and $23 \%$, respectively. Addition of potting mix as a source of SOM however also resulted in enrichment of some nutrients like N, S and Fe.

\subsection{Exposure scenario of nano- $\mathrm{CeO}_{2}$ to kidney bean plants}

As previously described (Majumdar et al., 2015), suspensions of nano- $\mathrm{CeO}_{2}$ in MPW were prepared upon 30 min bath sonication at $25^{\circ} \mathrm{C}(120 \mathrm{~V}, 3 \mathrm{Amps}, 50 / 60 \mathrm{~Hz})$. The total volume of the suspensions was adjusted to slightly smaller volume than the water holding capacity of the respective soils to prevent leaching and mass loss of the particles in each pot volume. The suspensions were mixed manually with the soils to achieve homogeneity and final concentrations of $62.5,125,250$, and $500 \mathrm{mg} / \mathrm{kg}$ in 4 and $3 \mathrm{~kg}$ of LOMS and OMES, respectively. The treated soils were then placed in 7 1/2" dia. x 6 " H plastic pots in quadruplicates, and were allowed to equilibrate for $24 \mathrm{~h}$. Soils mixed with only MPW were used for untreated controls.

Kidney bean (Phaseolus vulgaris var. Red Hawk) seeds provided by Dr. James Kelly from Michigan State University, were washed with 2\% sodium hypochlorite and MPW. Prior to sowing, the seeds were pre-soaked for $24 \mathrm{~h}$ in MPW. Fifteen seeds were equidistantly placed in each pot at a depth of $2.5 \mathrm{~cm}$ from the surface. Initially, the pots were placed in a growth chamber (Environmental Growth Chamber, Chagrin Falls, OH) with 14 h photoperiod (340 $\mu$ mole $\left.\mathrm{m}^{-2} \mathrm{~s}^{-1}\right), 25 / 20^{\circ} \mathrm{C}$ day/night temperature and $65-70 \%$ relative humidity for closer observation for 7 days until the appearance of the cotyledonous leaves. The pots were then transferred to a greenhouse with similar condition for 45 days. The plants in each pot were watered every day with $200 \mathrm{~mL}$ MPW for 15 days after planting. After the appearance of the first true leaves, the volume of irrigation water was increased to $400 \mathrm{ml}$ until harvest, with no significant leaching in any treatments. 


\subsection{Soil characterization after nano- $\mathrm{CeO}_{2}$ treatment}

Five grams of control and treated soils collected before sowing (BS) kidney bean seeds were air-dried. The BS soils were homogenized and sieved through $2 \mathrm{~mm}$ mesh prior to characterization. Although on sieving, nothing was retained in the $2 \mathrm{~mm}$ strain for LOMS, large aggregates of SOM was separated from OMES, which have been referred as OMES-OM in the following sections. All the fractions were stored for elemental analysis. Soil $\mathrm{pH}$ in water and $\mathrm{CaCl}_{2}$, EC and TDS were measured using Hanna Instruments HI 9813-6 Portable $\mathrm{pH} / \mathrm{EC} / \mathrm{TDS} /$ Temperature Meter. Cation exchange capacity (CEC) was measured by EPA Method 9081 (USEPA, 1986). Nitrogen content in the soils were determined using Kjeldahl method using a digestion and distillation unit (Labconco Co., Kansas city) and expressed as \% $\mathrm{N}$ (NTK) (Bremner, 1996). Soil micro- and macro-nutrient and Ce contents were also determined as discussed in section 2.7 .

After 52 days of plantation, a $12 \mathrm{~cm}$ deep soil column was sampled from each pot using a soil core sampler $(14 \mathrm{~cm} \times 1.5 \mathrm{~cm})$. The sampler is shown in the Supplementary Material (SM) Illustration S1. Each soil core was divided into three parts depending on the depth from the surface, the surface zone (SZ; 0-1 cm), the rhizospheric zone (RZ; 1-8 cm), and the bottom zone (BZ; 8-12 cm), as shown in SM Illustration S1. Soil samples from the three zones, the BS soils, and sieved SOM from OMES (OMES-OM) were further dried in an oven at $60{ }^{\circ} \mathrm{C}$ for $96 \mathrm{~h}$ to quantify the Ce content, as discussed later.

\subsection{Monitoring of plant gas exchange activities and photosynthetic pigment}

Leaf net photosynthetic rate $\left(\mathrm{P}_{\mathrm{n}}\right)$, stomatal conductance $\left(\mathrm{g}_{\mathrm{s}}\right)$, and transpiration $(\mathrm{E})$ of one plant per replicate were monitored after 52 days of exposure (DE) to $0-500 \mathrm{mg} / \mathrm{kg}$ nano-CeO ${ }_{2}$, by placing a fully expanded leaf in the cuvette of a portable gas exchange system (CIRAS-2; PP 
Systems, Amesbury, MA). The environmental conditions in the cuvette were controlled at a leaf temperature of $25^{\circ} \mathrm{C}$, photosynthetic photon flux (PPF) of $1000 \mu \mathrm{mol} \cdot \mathrm{m}^{-2} \cdot \mathrm{s}^{-1}$, and $\mathrm{CO}_{2}$

concentration of $375 \mu \mathrm{mol} \cdot \mathrm{mol}^{-1}$. The plants were well watered to avoid water stress, and the $P_{n}$, and $\mathrm{g}_{\mathrm{s}}$ E of four plants were recorded between 10:00 AM and 2:00 PM.

The major photosynthetic pigments in the leaves were extracted in $80 \%$ acetone. Chlorophyll $a$, chlorophyll $b$, and total carotenoids were measured as described by Lichtenthaler and Buschmann (2001).

\subsection{Plant harvest and growth related parameters}

After $52 \mathrm{DE}$, the plants were harvested and the lengths of primary root and stem from four plants in each replicate treatments were measured. The number of leaves in ten plants per replicate was noted. The area of the first true leaf of three plants per pot was determined using LI-3100C area meter (LI-COR ${ }^{\circledR}$ Biosciences, Lincoln, NE) after 52 DE.

Two plants from each pot composited as one sample from each replicate were used to determine $\mathrm{Ce}$ and micronutrient contents in the different tissues of the plant. The roots were carefully washed three times alternately with $0.1 \%$ plasma pure $\mathrm{HNO}_{3}$ and MPW to facilitate removal of adsorbed particles on the root surface and root hairs. The whole plant was then severed into roots, stems, and true leaves, which were dried for $96 \mathrm{~h}$ at $70{ }^{\circ} \mathrm{C}$ for further elemental analysis. The plants used for biochemical analyses were only washed thrice with MPW.

\subsection{Quantification of cerium and mineral nutrients in soil and plant tissues}

Dried roots, stems and leaves were digested in a mixture of plasma pure $\mathrm{HNO}_{3}$ and $30 \%$ (w/v) $\mathrm{H}_{2} \mathrm{O}_{2}$ (1:4) using microwave accelerated reaction system (CEM Mars $\mathrm{x}_{\mathrm{x}}$, Mathews, NC) following the U.S. EPA 3051 method (Packer et al., 2007). Accumulation of Ce and 
micronutrients (Al, B, Cu, Mn, Fe, $\mathrm{Zn}$ ) were analyzed in the digested tissues using inductively coupled plasma-optical emission spectroscopy (ICP-OES) (Optima 4300 DV, Perkin Elmer, Waltham, MA). The Ce and elemental (Al, Cu, Fe, Mn, Ni, Zn, Ca, K, Mg, P, S) contents in the aqua-regia digested soil samples (control and treated BS soils, core samples BZ, RZ and SZ of control and treated soils) were also determined using ICP-OES. Blanks, spikes, and certified standard reference material for plants (peach leaves NIST-SRM 1547) and soils (NIST-SRM 2709a San Joaquin Soil) were analyzed to validate the digestion process and spectroscopic analysis, obtaining 98\% recovery for Ce. The detection limit of ICP-OES was measured to be 1 $\mu \mathrm{g} / \mathrm{L}$. Also, $0.5 \mathrm{mg} / \mathrm{L}$ multi-elemental standard was analyzed every 10 samples to monitor the matrix effect on the analytes and for quality assurance/quality control (Majumdar et al., 2014).

\subsection{Antioxidant enzyme activity assays}

The fresh plants rinsed with MPW were severed into roots, stems, and leaves. The tissues were frozen immediately in liquid nitrogen and ground to fine powder. The powdered tissues were extracted in $50 \mathrm{mM}$ K-phosphate buffer containing $1 \mathrm{mM}$ EDTA, $1 \%$ PVP, and 0.5\% (v/v) Triton X-100. The $10 \%$ homogenates were centrifuged at $10,000 \times \mathrm{g}$ for $20 \mathrm{~min}$ (Eppendorf 5417R centrifuge, Hamburg, DE) (Gallego et al., 1996), and the supernatants were assayed to perform specific activity of catalase (CAT) and ascorbate peroxidase (APOX) according to Aebi (1974) and (Nakano and Asada, 1981), respectively. The enzyme activities were expressed as $\mu \mathrm{mol} \mathrm{H}_{2} \mathrm{O}_{2}$ decomposed $\mathrm{mg}^{-1}$ (tissue f wt) $\min ^{-1}$.

\subsection{Statistical analysis}

For comparison of untreated LOMS and OMES characteristics and quality, a two-tail Student t-test was used in paired comparisons. For all other grouped comparisons, the statistical analysis of the data was performed using one-way ANOVA followed by Tukey's multiple 
comparisons test based on a probability of $p \leq 0.05$ (Systat SigmaPlot 13.0 software). All analyses were performed in quadruplicates. A factorial two-way ANOVA was performed to examine the interaction between the two factors: nano- $\mathrm{CeO}_{2}(5$ treatments: $0,62.5,125,250$ and $500 \mathrm{mg} / \mathrm{kg}$ soil) and soil type (2 types: LOMS and OMES) on the soil characteristics and plant physiological/biochemical parameters. Post hoc comparison was carried out by Tukey's test to establish significance difference of $p \leq 0.05$ among means.

\section{Results and discussion}

\subsection{Effect of nano- $\mathrm{CeO}_{2}$ on soil properties and $\mathrm{Ce}$ distribution in soil horizons}

In this study, the amendment of the low and high organic matter containing soils with nano- $\mathrm{CeO}_{2}$ suspensions affected their physico-chemical properties. The general properties and micro- and macro-nutrient contents of the control and nano- $\mathrm{CeO}_{2}$ treated LOMS and OMES (sieved and OMES-OM) are shown in Table 1 and SM Table S1. The Ce content in the soils exposed to $0-500 \mathrm{mg} / \mathrm{kg}$ nano- $\mathrm{CeO}_{2}$ is presented in Figure 1. As Ce naturally occurs as a rare earth element, $38.4 \pm 0.8$ and $33.8 \pm 1.0 \mathrm{mg} / \mathrm{kg}$ Ce was found in sieved untreated LOMS and OMES, respectively. However, the exposure concentrations of nano- $\mathrm{CeO}_{2}$ were at significantly higher levels. LOMS and OMES exposed to 62.5 to $500 \mathrm{mg} / \mathrm{kg}$ nano- $\mathrm{CeO}_{2}$ treatments were analyzed for Ce content, which yielded $79.7 \pm 0.6$ to $386 \pm 9.6 \mathrm{mg} / \mathrm{kg}$ and $74.5 \pm 0.6$ to $350 \pm 27$ $\mathrm{mg} / \mathrm{kg} \mathrm{Ce}$, respectively in the sieved fraction $(\leq 2 \mathrm{~mm})$ in a dose-dependent manner (Figure 1$)$, as expected. OMES-OM fraction accumulated $4.9 \pm 2.9$ to $118 \pm 10 \mathrm{mg} / \mathrm{kg} \mathrm{Ce}$ at 62.5 to 500 $\mathrm{mg} / \mathrm{kg}$ nano- $\mathrm{CeO}_{2}$ exposure treatments. In a recent study by Zhang et al. (2016), higher concentration of oxidizable fraction of $\mathrm{CeO}_{2}$ was found in soil with higher organic matter, suggesting strong association of nano- $\mathrm{CeO}_{2}$ in soil with SOM. As Miracle Gro potting mixes are commercially sold as mix of nutrient supplements for plants, untreated OMES (10.1\% SOM) 
also had significantly higher levels of macronutrients like $\mathrm{N}$ and $\mathrm{S}$, and micronutrients like Fe, than LOMS (4.2\% SOM) (Table 1). As seen in Table 1, OMES also had significantly higher EC, TDS and CEC than LOMS $(p \leq 0.05)$. Thus, the OMES was more fertile and amenable for plant growth, owing to availability of higher concentrations of mineral nutrients. The addition of nano$\mathrm{CeO}_{2}$ to the soils however did not affect the soil $\mathrm{pH}$ and CEC. But, it significantly increased the EC and TDS at all the treatment concentrations in both soils, compared to their respective controls $(p \leq 0.05)$ (Table 1). At $500 \mathrm{mg} / \mathrm{kg}$, the EC and TDS increased by 127 and $149 \%$, respectively in LOMS and by 103 and 107\%, respectively in OMES with respect to their controls. Two-way ANOVA also suggested that the effect of nano- $\mathrm{CeO}_{2}$ treatment on the EC, TDS and \% TKN in the soils depended on the SOM content in situ, with interaction at $p \leq 0.001$. Nanoscale materials have been used for synthesis of ceramics, metals, alloys, or semiconductors, and composite materials for various applications due to its ability to increase EC (Rittner and Abraham, 1998). Thus, an increase in EC and TDS in the soils on nano- $\mathrm{CeO}_{2}$ addition was noted, irrespective of soil type. The measurement of both EC and TDS in the soils gives an indirect measurement of the salt content (Brady and Weil, 2008). An increase in EC and TDS signify an increase poor water filtration and drainage in the soil salinity, which may alter the soil fertility. Increased EC leads to poor water filtration and drainage thereby affecting plant health. In addition, Table 1 shows that at 250 and $500 \mathrm{mg} / \mathrm{kg}$ nano- $\mathrm{CeO}_{2}$ exposures, $\mathrm{Ca}, \mathrm{Mg}, \mathrm{Cu}, \mathrm{Fe}$ and $\mathrm{Zn}$ contents in the LOMS, and $\mathrm{K}, \mathrm{Mg}, \mathrm{Al}, \mathrm{Fe}, \mathrm{Mn}, \mathrm{Zn}$ in OMES decreased significantly compared to respective untreated soils. In contrary to our observations, Conway and Keller (2016) showed that at $100 \mathrm{mg} / \mathrm{kg}$ nano- $\mathrm{CeO}_{2}$, nano- $\mathrm{Cu}(\mathrm{OH})_{2}$ and nano- $\mathrm{TiO}_{2}, \mathrm{Mg}$ ion release was increased. However, as seen in SM Table S1, the micronutrients $\mathrm{Cu}, \mathrm{Fe}, \mathrm{Mn}$ contents were significantly higher in OMES-OM fraction of the OMES treated with $62.5 \mathrm{mg} / \mathrm{kg}$ by 59,58 and $51 \%$ 
compared to control. Sulfur content in OMES-OM was significantly higher at 125 and 500 $\mathrm{mg} / \mathrm{kg}$ OMES. The enhanced micronutrient in the organic fraction of the OMES with simultaneous accumulation of $\mathrm{Ce}$ per se, suggests that nano- $\mathrm{CeO}_{2}$ at low concentration may release elements more efficiently in the presence of organic matter. However, nano- $\mathrm{CeO}_{2}$ application within each soil type did not alter the CEC (Table 1), which measures the capacity of the soil to exchange cations like $\mathrm{Al}^{3+}, \mathrm{Ca}^{2+}, \mathrm{Mg}^{2+}, \mathrm{K}^{+}, \mathrm{NH}^{4+}, \mathrm{Na}^{+}$(Brady and Weil, 2008).

A soil core was obtained from each treatment replicate after 52 days of plant growth, which was further divided into surface, rhizosphere, and bottom zones, based on depth horizons. The Ce contents in each zone are shown in Figure 2. The ratios of Ce concentration in each zone to Ce concentration in the respective soils measured before sowing were similar $(0.80 \pm 0.02)$ between zones, soil types, and nano- $\mathrm{CeO}_{2}$ treatments. In support of our findings, Conway and Keller (2016) also showed that nano- $\mathrm{CeO}_{2}$ is primarily retained in the area of contamination with low rate of vertical transport in a soil column. The CEC in OMES was $43 \%$ higher than in LOMS, which suggests greater number of sites for exchange of the cations. The humus colloids in soils encourages aggregate stability and soil mineral decomposition, leading to increased availability of cationic nutrients in easily exchangeable form for the plants, without percolating through soil pores (Brady and Weil, 2008). In presence of SOM, low molecular weight organic acids such as humic and fulvic acids tend to form a coat around the nanoparticles (NPs), and stabilize them in the soil solution by electrostatic repulsion. This refrains the nanoparticles to aggregate among themselves or to soil components; thus, increasing their mobility in soil solution (Yang et al., 2009; Lin et al., 2010; Cornelis et al., 2014). However, adsorption and stabilization processes depend on the surface charge of the NPs and soil $\mathrm{pH}$. In this experiment, the alkaline soil environment favors the adsorption of the negatively charged groups of SOM to 
positively charged nano- $\mathrm{CeO}_{2}(11 \pm 2.5 \mathrm{mV}$, suspended in MPW $)$, thereby stabilizing these particles in the pore water. In LOMS, the surface charge of the heterogeneous soil colloids allows the nanoparticles to aggregate and thereby restrict their ability to pass through the soil pores (Schwabe et al., 2013). As shown by Zhang et al (2016), the major proportion of the Ce from nano- $\mathrm{CeO}_{2}$ in soil gets associated with the silicate minerals in the residual fraction. Moreover, at $100 \mathrm{mg} / \mathrm{kg}$ nano- $\mathrm{CeO}_{2}$, the residual fraction holds higher concentration of $\mathrm{Ce}$ in soils with lower SOM (Zhang et al., 2016), which decreases with increase in exposure concentration. Significant leaching was not observed in either soil, since the irrigation water was adjusted to the soil pore volume. Instead, the Ce concentration was homogeneous along $12 \mathrm{~cm}$ deep soil (Figure 2). This confirms that, regardless of one time nano- $\mathrm{CeO}_{2}$ supplementation and prolonged exposure condition, the plant roots were exposed to a homogenous Ce concentration in the soil throughout their life cycle. On closer observation, it was interesting to note that in OMES, at the highest nano- $\mathrm{CeO}_{2}$ treatment $(500 \mathrm{mg} / \mathrm{kg})$, a progressive increase was noted in $\mathrm{Ce}$ content with increasing soil depth in OMES, unlike in LOMS (Figure 2). The SZ, RZ and BZ of OMES contained $362 \pm 1.8,405 \pm 30,424 \pm 26 \mathrm{mg} / \mathrm{kg} \mathrm{Ce}$, respectively, whereas, in LOMS accumulated $379 \pm 2.1,362 \pm 4.2,359 \pm 40 \mathrm{mg} / \mathrm{kg}$ Ce, respectively. However, the variation among the zones were not significant enough to exclude the possibility that the difference was due to random sampling variability. Nevertheless, this trend corroborates the possibility of increased mobility in presence of higher SOM content.

\subsection{Uptake and accumulation of cerium and nutrients by the roots}

The accumulation of $\mathrm{Ce}$ in roots of kidney bean plants grown in $0-500 \mathrm{mg} / \mathrm{kg}$ nano- $\mathrm{CeO}_{2}$ amended LOMS and OMES for 52 days, is shown in Figure 3A. Micronutrient concentrations in roots exposed to $0-500 \mathrm{mg} / \mathrm{kg}$ nano- $\mathrm{CeO}_{2}$ amended LOMS and OMES are given in SM Figure 
$\mathrm{S} 1$. The $\mathrm{Ce}$ accumulation in roots exposed to nano- $\mathrm{CeO}_{2}$ was dose-dependent. At $62.5,125,250$ and $500 \mathrm{mg} / \mathrm{kg}$ nano- $-\mathrm{CeO}_{2}$, the LOMS roots accumulated $4.9 \pm 0.9,12.2 \pm 3.3,18.8 \pm 2.8$, and $24.9 \pm 1.4 \mathrm{mg} \mathrm{Ce} / \mathrm{kg}$ tissue $\mathrm{d} \mathrm{wt}$, respectively; and the OMES roots accumulated $2.8 \pm 0.8,8.5 \pm$ 2.9, $9.7 \pm 0.9$ and $22.8 \pm 6.8 \mathrm{mg} \mathrm{Ce} / \mathrm{kg}$ tissue $\mathrm{d}$ wt, respectively (Figure $3 \mathrm{~A}$ ). In LOMS, the root Ce concentrations were significantly higher in the plants exposed to $125-500 \mathrm{mg} / \mathrm{kg}$ with respect to control. Whereas in OMES, although the increase in root Ce concentration was dosedependent, the accumulation was significant only at $500 \mathrm{mg} / \mathrm{kg}$ nano- $-\mathrm{CeO}_{2}$. The dose-dependent accumulation of $\mathrm{Ce}$ in roots was not dependent on the soil type, as deduced from two-way ANOVA test. In addition, the supplementation of nano- $\mathrm{CeO}_{2}$ to $\mathrm{LOMS}$ or OMES did not affect the micro- or macro nutrient mobilization to plant roots (SM Figure S1).

The Ce accumulation in the kidney bean roots at $500 \mathrm{mg} / \mathrm{kg}$ nano- $\mathrm{CeO}_{2}(24.9 \pm 1.4$ and $22.8 \pm 6.8 \mathrm{mg} \mathrm{Ce} / \mathrm{kg} \mathrm{d}$ wt tissues in LOMS and OMES, respectively), were significantly lower than that reported in other soil based studies in soybeans (175 mg/kg d wt) (Priester et al., 2012), cucumber (317 mg/kg d wt) (Zhao et al., 2013), and corn (110 mg/kg dwt) (Zhao et al., 2015) at similar exposure concentrations. This could be a result of the interaction of the NPs with soil properties or species-dependent variation in response to nano- $\mathrm{CeO}_{2}$. However, in another study where Wang et al. (2012) supplied $10 \mathrm{mg} / \mathrm{L}$ nano- $\mathrm{CeO}_{2}$ chronically to the soil two times every week for 70 days leading to total input of $130 \mathrm{mg}$ nano- $-\mathrm{CeO}_{2} / \mathrm{kg}$ soil, the tomato roots accumulated up to $12 \mathrm{mg} / \mathrm{kg} \mathrm{d}$ wt. The accumulation in the tomato roots corroborate to our observations at a similar exposure concentration of $125 \mathrm{mg} / \mathrm{kg}$ nano- $\mathrm{CeO}_{2}$ in $\mathrm{LOMS}$ as well as OMES. High resolution imaging techniques using transmission electron microscopy and synchrotron X-ray micro-spectroscopy have provided evidences that a large fraction of nano$\mathrm{CeO}_{2}$ is adsorbed by the root hairs (Majumdar et al., 2014), and is internalized with minimum 
biotransformation (Zhang et al., 2012; Hernandez-Viezcas et al., 2013; Majumdar et al., 2014). In LOMS, the soil colloids and minerals tend to bind to the nano- $\mathrm{CeO}_{2}$, leading to aggregation and larger size (Quik et al., 2010; Cornelis et al., 2014), thereby reducing the mobility in the pore spaces. Thus, the nano- $\mathrm{CeO}_{2}$ may primarily remain either incorporated in the root epidermal layers (Zhang et al., 2012; Majumdar et al., 2014) or bound to root exudates, leading to higher adsorption or localized accumulation in the roots. On the other hand, in OMES, the organic matter stabilizes the nano- $\mathrm{CeO}_{2}$ in the pore spaces and they remain dispersed maintaining their nanoparticulate size or remaining as small aggregates (Yang et al., 2009; Schwabe et al., 2013). This enables the nano- $\mathrm{CeO}_{2}$ to penetrate root barriers, and more accessible to the vascular tissues (Figure 3B). In contrast to our findings, Zhao et al. (2012) reported significantly lower root accumulation of $\mathrm{Ce}$ in the unenriched soil, compared to enriched soil. Also, radish fine roots exposed to $500 \mathrm{mg} / \mathrm{kg}$ nano- $\mathrm{CeO}_{2}$ in silty loam soil with $\sim 2 \% \mathrm{SOM}$, accumulated higher concentration of $\mathrm{Ce}$, compared to loamy sand soil containing $\sim 12 \%$ SOM (Zhang et al., 2016).

\subsection{Translocation of cerium from roots to leaves}

The concentration of $\mathrm{Ce}$ in the leaves of plants grown in LOMS and OMES amended with 0-500 mg/kg nano- $\mathrm{CeO}_{2}$ has been provided in Figure 3B. The Ce concentration in the stems were below the detection limit of ICP-OES. Leaves in control plants grown in LOMS and OMES showed 0.13 and $0.16 \mathrm{mg} / \mathrm{kg}$ of Ce, respectively, which could be due to the presence of $\mathrm{Ce}$ in the natural soil. Even though at $62.5 \mathrm{mg} / \mathrm{kg}$ nano- $\mathrm{CeO}_{2}$, Ce was not detected in leaf tissues, with increasing nano- $\mathrm{CeO}_{2}$ exposure concentration $(125-500 \mathrm{mg} / \mathrm{kg})$, the leaves accumulated $0.19 \pm$ $0.12,0.3 \pm 0.1,0.6 \pm 0.1 \mathrm{mg} \mathrm{Ce} / \mathrm{kg} \mathrm{d}$ wt in LOMS plants and $0.3 \pm 0.1,0.4 \pm 0.2,1.1 \pm 0.3 \mathrm{mg}$ $\mathrm{Ce} / \mathrm{kg} \mathrm{d} \mathrm{wt}$ in OMES plants. The plants in both soils accumulated the highest Ce concentration in leaves at $500 \mathrm{mg} / \mathrm{kg}$ at a significantly higher level $(p \leq 0.05)$, compared to respective controls. 
Unlike in roots, the $\mathrm{Ce}$ content in the leaves of nano- $\mathrm{CeO}_{2}$ exposed kidney bean plants were considerably higher than in soybean $(0.000247 \mathrm{mg} / \mathrm{kg} \mathrm{d}$ wt) (Priester et al., 2012), whereas similar to cucumber (1.72 mg/kg d wt) (Zhao et al., 2013), corn (1.84 mg/kg d wt) (Zhao et al., 2015 ) and tomato $\left(0.97 \mathrm{mg} / \mathrm{kg} \mathrm{d} \mathrm{wt}\right.$ ) (Barrios et al., 2015) plants at $400-500 \mathrm{mg} / \mathrm{kg}$ nano- $\mathrm{CeO}_{2}$. As shown in SM Table S2, Ce translocation factor in kidney bean plants was 0.02-0.03 in LOMS and 0.04-0.05 in OMES. Furthermore, the translocation of Ce to the kidney bean leaves was 65 , 44, $71 \%$ higher in OMES than LOMS at 125,250 and $500 \mathrm{mg} / \mathrm{kg}$ nano- $-\mathrm{CeO}_{2}$ treatments. This indicates that the Ce translocation to the aerial tissues in the kidney bean plants was enhanced by the increase in SOM. Dissolved organic matter in soil has been reported to stabilize metal oxide NPs, depending on their surface charge by ligand exchange between different aliphatic and phenolic groups on the surface of humic acids, and the ions at the surface of the uncoated or coated ENMs (Yang et al., 2009; Cornelis et al., 2014). Thus, in our study, the dissolved organic matter from the OMES likely makes $\mathrm{Ce}$ from nano- $\mathrm{CeO}_{2}$ more bioavailable to the plants due to better dispersion and stabilization of the particles in the porous media (Conway and Keller, 2016). Zhang et al. (2016) reported that the behavior of nano- $\mathrm{CeO}_{2}$ in soil and plant strongly depends on soil properties. In addition, the Ce translocation to the aboveground tissues could depend on the presence of Ce ions in the roots (Zhang et al., 2016). However, ionization of the Ce in the plant tissues in situ, in response to SOM presence, was not explored in this study. A previous study from the Gardea group has also shown that significantly more Ce is present in the soil solution extracted from nano- $\mathrm{CeO}_{2}$ spiked soils in presence of higher SOM (Zhao et al., 2012). In contrast to our findings, shoots from corn plants grown in organic soil spiked with uncoated and alginate-coated nano- $\mathrm{CeO}_{2}$ accumulated significantly lower mg of $\mathrm{Ce} / \mathrm{kg} \mathrm{d} \mathrm{wt}$ tissues compared to those grown in unenriched soil (Zhao et al., 2012). The authors suggested 
that the carboxylate and phenolate groups in the humus bind to the nano- $\mathrm{CeO}_{2}$, leading to lower translocation in presence of higher organic matter. This disparity between the previous reports and the current observations could be due to a species-associated response or variations in plant vasculature.

\subsection{Impact of nano- $\mathrm{CeO}_{2}$ on plant growth}

The length of the roots and shoots, and the number and area of leaves of plants exposed to $0-500 \mathrm{mg} / \mathrm{kg}$ LOMS and OMES are presented in SM Table S3. Plant growth parameters including root and shoot length were not affected across $\mathrm{SOM}$ content or nano- $\mathrm{CeO}_{2}$ exposures. Additionally, the number of leaves per plant was not affected; however, the leaf area was increased significantly $(p \leq 0.05)$ only in LOMS plants exposed to $62.5,250$ and $500 \mathrm{mg} / \mathrm{kg}$ nano- $\mathrm{CeO}_{2}$ by 105,90 and $111 \%$, respectively, compared to control plants. There was no apparent effect on the vegetative growth parameters (roots, stems or leaves) in nano- $\mathrm{CeO}_{2}$ exposed OMES grown plants.

Due to the evident growth enhancement, antioxidant, and bio-compatible properties of $\mathrm{CeO}_{2}$, its nanoparticulate form has invited significant attention in agriculture and biomedicine in recent years. Current nanotoxicity studies are more focused on life cycle exposure scenarios (Priester et al., 2012; Zhao et al., 2015; Majumdar et al., 2015) across different types of ENMs and under different environmental conditions (Conway et al., 2015), to benefit their risk assessment in realistic conditions for regulatory measures. Similar to our observations in kidney bean plants, some previous studies have also reported inconsequential effects on overall growth of roots and shoots of cucumber (Zhao et al., 2013), corn (Zhao et al., 2015), and wheat (Du et al., 2015). In tomato plants, Wang et al. (2012) showed no significant effects on the plant length on chronic exposure to $0.1-10 \mathrm{mg} / 1$ nano- $\mathrm{CeO}_{2}$, building upto $130 \mathrm{mg} / \mathrm{kg}$ Ce in soil, Barrios et al. 
(2015) found a decrease in stem growth at 62.5 and $125 \mathrm{mg} / \mathrm{kg}$ nano- $\mathrm{CeO}_{2}$; however, at higher concentrations, there was no significant difference with respect to control. Priester et al. (2012) also showed decrease in soybean shoot length at 100 and $500 \mathrm{mg} / \mathrm{kg}$ nano- $\mathrm{CeO}_{2}$ exposure in soil. Although in kidney beans there was a slight decrease in shoot length when grown in OMES, but the variation was not significantly different, compared to control plants. As seen in SM Table S3, the increase in leaf cover area in plants grown in nano- $\mathrm{CeO}_{2}$ amended $\mathrm{LOMS}$ could be attributed to beneficial or growth enhancement effects of Ce ions up to certain concentrations (Weiping et al., 2003; Yuguan et al., 2009; Shyam and Aery, 2012; Thomas et al., 2014). However, the leaf count and cover area in OMES plants was unaffected by nano- $\mathrm{CeO}_{2}$ exposure, similar to previous findings in soybean, corn, and cucumber plants (Priester et al., 2012; Zhao et al., 2013; Zhao et al., 2015) grown in unenriched soils. Due to higher translocation in OMES plants, at all nano- $\mathrm{CeO}_{2}$ exposure concentrations, the Ce content in OMES leaves was higher than LOMS leaves. Thus, the correlation between leaf growth and Ce content per se is debatable. Similar to the kidney bean roots (SM Figure S1), micronutrient contents in the aerial tissues were not affected as shown in SM Table S4 and S5; thus, the expanding leaf cover area in nano- $\mathrm{CeO}_{2}$ exposed LOMS plants seems not related with the micronutrient content. More studies are needed in order to fully understand the response of plants to nano- $\mathrm{CeO}_{2}$ exposure in difference soil matrices. Studies utilizing electron microscopy and synchrotron XRF micro-spectroscopy have shown that the $\mathrm{Ce}$ taken up by plants is in the form of nano- $\mathrm{CeO}_{2}$ as well as dissolved $\mathrm{Ce}$ (III) ions (Zhang et al., 2012) (Hernandez-Viezcas et al., 2013) (Majumdar et al., 2014). The dissolution of Ce (III) from the NP could occur in the growth media (Schwabe et al., 2015) in the presence of root exudates, soil minerals and SOM, in the root epidermis at point of entry or 
inside the plants. Further studies are required to examine how the presence or absence of SOM may affect the speciation of the metals in metal oxide NPs before and after entering plants.

\subsection{Impact on photosynthetic pigments, photosynthesis and gas exchange activities}

Photosynthesis is a major metabolic process in plants, responsible for capturing light energy for the synthesis of energy producing molecules, and is thus vulnerable to abiotic stress factors (Taiz and Zeiger, 1998). Adverse impact on the photosynthetic pigments in the leaves can affect the regulation of photosynthesis. Photosynthesis is simultaneously associated with other gas exchange activities like transpiration and stomatal conductance, which regulate the plant metabolic processes. The effect of nano- $\mathrm{CeO}_{2}$ exposure on photosynthetic pigment contents (chlorophyll $a$, chlorophyll $b$, and carotenoids) in the leaves of kidney bean plants grown in LOMS and OMES is given in Figure 4. In LOMS, the effect of nano- $\mathrm{CeO}_{2}$ on the leaf photosynthetic pigments was inconsequential with the exception of chlorophyll $a$, which increased at all nano- $\mathrm{CeO}_{2}$ treatments; however, the increase (37\%) was statistically significant only at $250 \mathrm{mg} / \mathrm{kg}$ nano- $\mathrm{CeO}_{2}$ exposure concentration (Figure 4A). In contrast, the chlorophyll $a$ and carotenoid content in leaves from nano- $\mathrm{CeO}_{2}$ amended-OMES plants showed a decreasing trend (Figure 4B). In OMES leaves, the chlorophyll $a$ decreased by 27 and 18\% after 52 days exposure to 125 and $250 \mathrm{mg} / \mathrm{kg}$ nano- $-\mathrm{CeO}_{2}$; and, the carotenoid content decreased by $25-28 \%$ on exposure to $62.5-250 \mathrm{mg} / \mathrm{kg}$ nano- $\mathrm{CeO}_{2}$. This indicates that the higher translocation of nano$\mathrm{CeO}_{2}$ to the leaves in OMES, leads to reduction in the photosynthetic pigments, which absorb light energy from the sunlight at certain wavelength, and transfer energy in a particular sequence to carry out photosynthesis (Taiz and Zeiger, 1998). However, Ce translocation dependent decrease in photosynthetic pigment did not hold true at the highest exposure concentration in OMES $\left(500 \mathrm{mg} / \mathrm{kg}\right.$ nano- $\mathrm{CeO}_{2}$ ), where the content of chlorophyll $a$ and total carotenoids in the 
kidney bean leaves were restored to control levels. Although, the nano- $\mathrm{CeO}_{2}$ affected the chlorophyll content in the LOMS and OMES leaves, the chlorophyll $a$ /chlorophyll $b$ ratio was not altered.

Physiological processes including transpiration, stomatal conductance, and net photosynthesis of the LOMS and OMES plants exposed to nano- $\mathrm{CeO}_{2}$ are shown in Figure 5. In LOMS plants, only at $62.5 \mathrm{mg} / \mathrm{kg}$ nano- $\mathrm{CeO}_{2}$ exposure, the net photosynthesis was increased significantly by $157 \%$, compared to control (Figure 5C). The simultaneous increase in transpiration rate and stomatal conductance of LOMS plants at $62.5,250$ and $500 \mathrm{mg} / \mathrm{kg}$ nano$\mathrm{CeO}_{2}$ exposure was statistically insignificant (Figure 5A, B). However, in the OMES plants, at all nano- $\mathrm{CeO}_{2}$ exposures, the net photosynthesis were significantly higher than the control, but the increase was statistically inconsequential. The stomatal conductance in OMES plants increased significantly at all exposure concentrations $(131 \pm 17,207 \pm 27,194 \pm 14,125 \pm 32$ $\mathrm{mmol} \mathrm{m}{ }^{-2} \mathrm{~s}^{-1}$ at $62.5,125,250$ and $500 \mathrm{mg} / \mathrm{kg}$ nano- $\mathrm{CeO}_{2}$ ) compared to control plants $(31 \pm 6$ $\left.\mathrm{mmol} \mathrm{m} \mathrm{s}^{-1}\right)$. The transpiration rate was also increased from $0.7 \pm 0.1 \mathrm{mmol} \mathrm{m}^{-2} \mathrm{~s}^{-1}$ in control plants to $2.4 \pm 0.3,3.8 \pm 0.7,3.0 \pm 0.1$, and $2.3 \pm 0.3 \mathrm{mmol} \mathrm{m}^{-2} \mathrm{~s}^{-1}$ at $62.5,125$ and $250 \mathrm{mg} / \mathrm{kg}$ nano- $\mathrm{CeO}_{2}$ exposures, respectively. As seen in Figure 5, the transpiration rate and stomatal conductance was maximum in the $125 \mathrm{mg} / \mathrm{kg}$ nano- $\mathrm{CeO}_{2}$ exposed OMES plants, which increased by 380 and $207 \%$ than control plants. A significant interaction between the soil type and the nano- $\mathrm{CeO}_{2}$ exposure concentration was reported for transpiration rate and stomatal conductance.

Similar to our observations in LOMS plants, previous studies on tomato, corn, cucumber and radish have also noted insignificant to slight increase in chlorophyll content on exposure to nano- $\mathrm{CeO}_{2}$ (Wang et al., 2012; Zhao et al., 2013; Zhao et al., 2015; Barrios et al., 2015; Zh). In 
another study, Rico et al. (2015) showed that the chlorophyll content in barley leaves was increased at $125-500 \mathrm{mg} / \mathrm{kg}$ nano- $\mathrm{CeO}_{2}$, similar to our observations in LOMS leaves. The slight increase in the chlorophyll $a$ is well correlated with the increase in leaf cover areas in LOMS plants on exposure to nano- $\mathrm{CeO}_{2}$ ( $\mathrm{SI}$ Table S3). As shown in many studies, although nano- $\mathrm{CeO}_{2}$ may cause alterations in some physiological parameters, it does not exert overt toxicity on the plant growth, which could be due to its facile transition between oxidation states (Caputo et al., 2015) acting as a buffer in redox processes or low dissolution (Majumdar et al., 2014; Zhang et al., 2016). Cerium oxide is also used in many parts of the world as fertilizers to improve crop growth and yield. Researchers have shown nano- $\mathrm{CeO}_{2}$ to initiate protective mechanisms in the plants by upregulation of heat shock proteins (Zhao et al., 2012), or by mimicking the activities of antioxidant enzymes like superoxide dismutase or catalase (McCormack et al., 2014). This also explains the minimum effects on the photosynthetic system and gas exchange in the LOMS plants exposed to nano- $\mathrm{CeO}_{2}$. Interestingly, the adverse impact on the photosynthetic activities and water transport was much higher in OMES than in LOMS plants exposed to nano- $\mathrm{CeO}_{2}$. In the OMES plants, the effects on the photosynthetic pigment contents and the photosynthetic activities are contrasting, as these activities are dependent on the pigments to absorb the various wavelengths from sunlight. Our findings are in agreement with previous studies showing reduction in chlorophyll $a$ content in wheat plants grown in 100 and $400 \mathrm{mg} / \mathrm{kg}$ nano- $-\mathrm{CeO}_{2}$ contaminated field (Du et al., 2015). However, simultaneous increase in the gas exchange activities was interesting to note. As noted in our translocation study, Ce was translocated better in the presence of higher SOM content (Figure 3B). It could be possible that although the nano$\mathrm{CeO}_{2}$ decreases the photosynthetic pigments in the leaves, it simultaneously increases the photosynthetic efficiency of the plants. Cerium has been shown to improve the photosynthetic 
efficiency of soybean seedlings (Liang et al., 2006). Our observation provide evidences that the alteration in the plant metabolic activities is dependent on the SOM content. As the mechanism of the enhancement in the gas exchange activities in response to nano- $\mathrm{CeO}_{2}$ is still unknown, further kinetic and competitive studies may be required using photosynthetic enzymes for better clarification.

\subsection{Impact of nano- $\mathrm{CeO}_{2}$ on antioxidant enzyme activities}

Figure 6 shows the activities of antioxidant enzymes in roots, stems and leaves in the plants grown in $0-500 \mathrm{mg} / \mathrm{kg}$ nano- $\mathrm{CeO}_{2}$. The $\mathrm{APOX}$ and $\mathrm{CAT}$ activities in the roots exposed to nano- $\mathrm{CeO}_{2}$ were not affected. In the stems, CAT activity was increased on exposure to 62.5-500 $\mathrm{mg} / \mathrm{kg}$ nano- $\mathrm{CeO}_{2}$ only in LOMS. Additionally, the enzyme activities were not affected in LOMS leaves. However in OMES leaves, CAT activity was significantly increased at 62.5 $\mathrm{mg} / \mathrm{kg}$ nano- $\mathrm{CeO}_{2}$ exposure by $177 \%$ compared to control (Figure $6 \mathrm{~B}$ ), and APOX activity was increased at $125-500 \mathrm{mg} / \mathrm{kg}$ nano- $\mathrm{CeO}_{2}$ exposure by 465 and $362 \%$, respectively, compared to control (Figure 6A). Differential CAT response in the shoots from kidney bean plants grown in soil with varying SOM contents validates that the CAT mimetic activity of $\mathrm{CeO}_{2}$ is enhanced with more SOM in the growth media, due to stabilization of $\mathrm{CeO}_{2}$ before entering the plants. In agreement with our observations in roots and leaves, Barrios et al. (2015) found no effect on CAT activities in tomato plants exposed to pristine nano- $\mathrm{CeO}_{2}$; however the CAT activity in the plants was increased upon exposure to more stable citric acid-coated $\mathrm{CeO}_{2}$. In barley leaves, CAT activity was not affected, but APOX activity increased significantly at $125-500 \mathrm{mg} / \mathrm{kg}$ nano- $\mathrm{CeO}_{2}$ exposure in soil (Rico et al., 2015). In another recent study, Ma et al. (2016) reported that CAT or superoxide dismutase activity in the Brassica rapa plants was not affected by every 2 day chronic addition of fixed volume $(20 \mathrm{ml})$ of 10 and $1000 \mathrm{mg} / \mathrm{L}$ nano- $\mathrm{CeO}_{2}$ for 17 days (net addition of 32 and $320 \mathrm{mg} / \mathrm{kg}$ nano- $\mathrm{CeO}_{2}$, respectively). In accordance with our supporting evidence on the differential response to nano- $\mathrm{CeO}_{2}$ exposure with varying $\mathrm{SOM}$ content, the 
stress response in kidney bean plants grown in OMES was thus more pronounced than in LOMS. In the OMES plants, although the CAT was responsible to combat stress in the leaf tissues at $62.5 \mathrm{mg} / \mathrm{kg}$ nano- $\mathrm{CeO}_{2}$ exposure, the APOX acted as the primary antioxidant enzyme to fight the stress from $125-500 \mathrm{mg} / \mathrm{kg}$ nano- $\mathrm{CeO}_{2}$ exposures.

\section{Conclusions}

Among other soil properties, natural organic matter influences the behavior of nanoparticles in the soils as well as their effects on plants. This study clearly states that enhancement of organic matter in the soil increases the mobility of the nano- $\mathrm{CeO}_{2}$ within the plants. This leads to easier access of the nano- $\mathrm{CeO}_{2}$ to the metabolic machinery of the plants, which alters physiological activities in the leaves pertaining to food and energy production and plant health. On the other hand, in natural sandy loam soil with low organic matter, the nano$\mathrm{CeO}_{2}$ aggregated or attached to soil grain surface due to opposite charge, and thus restricted primarily to the below ground biomass. This study suggests that fate, bioavailability and biological effects of nano- $\mathrm{CeO}_{2}$ are highly dependent on the properties of the complex soil matrix. Further investigations are required in the rhizospheric region to understand how the soil physico-chemical properties influence the chemistry between nano- $\mathrm{CeO}_{2}$, plant roots and soil components. This may help in a better understanding of the mechanisms by which the nano$\mathrm{CeO}_{2}$ affect plant health and major metabolic functions.

\section{Acknowledgements}

This material is based upon work supported by the National Science Foundation and the Environmental Protection Agency under Cooperative Agreement Number DBI-1266377. Any opinions, findings, and conclusions or recommendations expressed in this material are those of the author(s) and do not necessarily reflect the views of the National Science Foundation or the 
Environmental Protection Agency. This work has not been subjected to EPA review, and no official endorsement should be inferred. This work was also supported by Grant 2G12MD007592 from the National Institutes on Minority Health and Health Disparities (NIMHD), a component of the National Institutes of Health (NIH). Authors also acknowledge the USDA grant 2011-38422-30835 and the NSF Grants CHE-0840525 and DBI-1429708. Partial funding was provided by the NSF ERC on Nanotechnology-Enabled Water Treatment (EEC-1449500). J. L. Gardea-Torresdey acknowledges the Dudley family for the Endowed Research Professorship, the Academy of Applied Science/US Army Research Office, Research, and Engineering Apprenticeship program (REAP) at UTEP, grant \# W11NF-10-2-0076, subgrant 13-7, and STARs programs of the University of Texas System.. We also acknowledge Dr. James D. Kelly, Michigan State University for generously providing kidney bean seeds for this research.

\section{References}

Aebi, H., Catalase A2 - Bergmeyer, Hans Ulrich, in: Methods of Enzymatic Analysis (Second Edition), Academic Press, 1974, pp. 673-684.

Barrios, A. C., Rico, C. M., Trujillo-Reyes, J., Medina-Velo, I. A., Peralta-Videa, J. R., GardeaTorresdey, J. L., 2015. Effects of uncoated and citric acid coated cerium oxide nanoparticles, bulk cerium oxide, cerium acetate, and citric acid on tomato plants. Sci. Total Environ.

DOI:10.1016/j.scitotenv.2015.11.143

Brady, N. C., Weil, R. R., The Nature and Properties of Soils, 13 ed., Pearson Prentice Hall, 2008.

Bremner, J. M., Total nitrogen, in: Sparks, D.L. (Ed.) Methods of soil analysis. Part 3. Chemical methods, Soil Science Society of America: American Society of Agronomy, Madison, Wisconsin, 1996, pp. 1035-1122.

Caputo, F., De Nicola, M., Sienkiewicz, A., Giovanetti, A., Bejarano, I., Licoccia, S., Traversa, E., Ghibelli, L., 2015. Cerium oxide nanoparticles, combining antioxidant and UV shielding properties, prevent UV-induced cell damage and mutagenesis. Nanoscale. 7, 15643-15656. 
Collin, B., Auffan, M., Johnson, A. C., Kaur, I., Keller, A. A., Lazareva, A., Lead, J. R., Ma, X., Merrifield, R. C., Svendsen, C., White, J. C., Unrine, J. M., 2014. Environmental release, fate and ecotoxicological effects of manufactured ceria nanomaterials. Environ. Sci.: Nano 1, 533-548.

Conway, J. R., Beaulieu, A. L., Beaulieu, N. L., Mazer, S. J., Keller, A. A., 2015. Environmental Stresses Increase Photosynthetic Disruption by Metal Oxide Nanomaterials in a Soil-Grown Plant. ACS Nano 9, 11737-11749.

Conway, J. R.; Keller, A. A., 2016. Gravity-driven transport of three engineered nanomaterials in unsaturated soils and their effects on soil pH and nutrient release. Water Res. 98, 250-260.

Cornelis, G., Hund-Rinke, K., Kuhlbusch, T., van den Brink, N., Nickel, C., 2014. Fate and Bioavailability of Engineered Nanoparticles in Soils: A Review. Critical Reviews in Environ. Sci. Technol. 44, 2720-2764.

Domingos, R. F.; Tufenkji, N.; Wilkinson, K. J., 2009. Aggregation of Titanium Dioxide Nanoparticles: Role of a Fulvic Acid. Environ. Sci. Technol. 43, 1282-1286.

Du, W., Gardea-Torresdey, J. L., Ji, R., Yin, Y., Zhu, J., Peralta-Videa, J. R., Guo, H., 2015. Physiological and Biochemical Changes Imposed by $\mathrm{CeO} 2$ Nanoparticles on Wheat: A Life Cycle Field Study. Environ. Sci. Technol. 49, 11884-11893.

Gallego, S. M., Benavídes, M. P., Tomaro, M. L., 1996. Effect of heavy metal ion excess on sunflower leaves: evidence for involvement of oxidative stress. Plant Sci. 121, 151-159.

Gardea-Torresdey, J. L., Rico, C. M., White, J. C., 2014. Trophic Transfer, Transformation, and Impact of Engineered Nanomaterials in Terrestrial Environments. Environ. Sci. Technol. 48, 25262540 .

Garner, K. L.; Keller, A. A., 2014. Emerging patterns for engineered nanomaterials in the environment: a review of fate and toxicity studies. J. Nanopart. Res. 16, 1-28.

Hawthorne, J., De la Torre Roche, R., Xing, B., Newman, L. A., Ma, X., Majumdar, S., GardeaTorresdey, J., White, J. C., 2014. Particle-Size Dependent Accumulation and Trophic Transfer of Cerium Oxide through a Terrestrial Food Chain. Environ. Sci. Technol. 48, 13102-13109.

Hernandez-Viezcas, J. A., Castillo-Michel, H., Andrews, J. C., Cotte, M., Rico, C., Peralta-Videa, J. R., Ge, Y., Priester, J. H., Holden, P. A., Gardea-Torresdey, J. L., 2013. In Situ Synchrotron X-ray Fluorescence Mapping and Speciation of $\mathrm{CeO} 2$ and $\mathrm{ZnO}$ Nanoparticles in Soil Cultivated Soybean (Glycine max). ACS Nano 7, 1415-1423.

Holden, P. A.; Gardea-Torresdey, J. L.; Klaessig, F.; Turco, R. F.; Mortimer, M.; Hund-Rinke, K. et al., 2016. Considerations of Environmentally Relevant Test Conditions for Improved Evaluation of Ecological Hazards of Engineered Nanomaterials. Environ. Sci. Technol. DOI: 10.1021/acs.est.6b00608.

Johnson, R. L., Johnson, G. O. B., Nurmi, J. T., Tratnyek, P. G., 2009. Natural Organic Matter Enhanced Mobility of Nano Zerovalent Iron. Environ. Sci. Technol. 43, 5455-5460. 
Judy, J. D., Unrine, J. M., Bertsch, P. M., 2011. Evidence for Biomagnification of Gold Nanoparticles within a Terrestrial Food Chain. Environ. Sci. Technol. 45, 776-781.

Kah, M., Beulke, S., Tiede, K., Hofmann, T., 2013. Nanopesticides: State of Knowledge, Environmental Fate, and Exposure Modeling. Critical Reviews in Environ. Sci. Technol. 43, 18231867.

Keller, A. A., Wang, H., Zhou, D., Lenihan, H. S., Cherr, G., Cardinale, B. J., Miller, R., Ji, Z., 2010. Stability and Aggregation of Metal Oxide Nanoparticles in Natural Aqueous Matrices. Environ. Sci. Technol. 44, 1962-1967.

Keller, A. A.; Lazareva, A., 2014. Predicted Releases of Engineered Nanomaterials: From Global to Regional to Local. Environ. Sci. Technol. Lett. 1, 65-70.

Liang, C.-j., Huang, X.-h., Zhou, Q., 2006. Effect of cerium on photosynthetic characteristics of soybean seedling exposed to supplementary ultraviolet-B radiation. J. Environ. Sci. 18, 1147-1151.

Lichtenthaler, H. K., Buschmann, C., Chlorophylls and Carotenoids: Measurement and Characterization by UV-VIS Spectroscopy, in: Current Protocols in Food Analytical Chemistry, John Wiley \& Sons, Inc., 2001.

Lin, D., Tian, X., Wu, F., Xing, B., 2010. Fate and transport of engineered nanomaterials in the environment. J. Environ. Qual. 39, 1896-1908.

Liu, H. H., Cohen, Y., 2014. Multimedia environmental distribution of engineered nanomaterials. Environ. Sci. Technol. 48, 3281-3292.

Majumdar, S., Peralta-Videa, J. R., Bandyopadhyay, S., Castillo-Michel, H., Hernandez-Viezcas, J.A., Sahi, S., Gardea-Torresdey, J. L., 2014. Exposure of cerium oxide nanoparticles to kidney bean shows disturbance in the plant defense mechanisms. J. Hazard. Mater. 278, 279-287.

Majumdar, S., Almeida, I. C., Arigi, E. A., Choi, H., VerBerkmoes, N. C., Trujillo-Reyes, J., FloresMargez, J. P., White, J. C., Peralta-Videa, J. R., Gardea-Torresdey, J. L., 2015. Environmental Effects of Nanoceria on Seed Production of Common Bean (Phaseolus vulgaris): A Proteomic Analysis. Environ. Sci. Technol. 49, 13283-13293.

Majumdar, S., Trujillo-Reyes, J., Hernandez-Viezcas, J. A., White, J. C., Peralta-Videa, J. R., GardeaTorresdey, J. L., 2015. Cerium Biomagnification in a Terrestrial Food Chain: Influence of Particle Size and Growth Stage. Environ. Sci. Technol. DOI: 10.1021/acs.est.5b04784

Ma, X.; Wang, Q.; Rossi, L.; Zhang, W., 2016. Cerium oxide nanoparticles and bulk cerium oxide leading to different physiological and biochemical responses in Brassica rapa. Environ. Sci. Technol. DOI: $10.1021 /$ acs.est.5b04111.

Ma, X.; Wang, Q.; Rossi, L.; Ebbs, S. D.; White, J. C., 2016. Multigenerational exposure to cerium oxide nanoparticles: Physiological and biochemical analysis reveals transmissible changes in rapid cycling Brassica rapa. NanoImpact, 1, 46-54.

McCormack, R. N., Mendez, P., Barkam, S.,Neal, C. J., Das, S., Seal, S., 2014. Inhibition of Nanoceria's Catalytic Activity due to Ce3+ Site-Specific Interaction with Phosphate Ions. The J. Phys. Chem. C 118, 18992-19006. 
McKenzie, N., Jacquier, D., Isbell, R., Brown, K., 2004. Australian Soils and Landscapes. Collingwood

Nakano, Y., Asada, K., 1981. Hydrogen Peroxide is Scavenged by Ascorbate-specific Peroxidase in Spinach Chloroplasts. Plant Cell Physiol. 22, 867-880.

Nguyen, K. T., Zhao, Y., 2015. Engineered Hybrid Nanoparticles for On-Demand Diagnostics and Therapeutics. Acc. Chem. Res. 48, 3016-3025.

Packer, A. P., Larivière, D., Li, C., Chen, M., Fawcett, A., Nielsen, K., Mattson, K., Chatt, A., Scriver, C., Erhardt, L. S., 2007. Validation of an inductively coupled plasma mass spectrometry (ICP-MS) method for the determination of cerium, strontium, and titanium in ceramic materials used in radiological dispersal devices (RDDs). Anal. Chim. Acta 588, 166-172.

Peijnenburg, W. J. G. M., Baalousha, M., Chen, J., Chaudry, Q., Von der kammer, F., Kuhlbusch, T. A. J., Lead, J., Nickel, C., Quik, J. T. K., Renker, M., Wang, Z., Koelmans, A. A., 2015. A Review of the Properties and Processes Determining the Fate of Engineered Nanomaterials in the Aquatic Environment. Critical Reviews in Environ. Sci. Technol. 45, 2084-2134.

Priester, J. H., Ge, Y., Mielke, R. E., Horst, A. M., Moritz, S. C., Espinosa, K., Gelb, J., Walker, S. L., Nisbet, R. M., An, Y.-J., Schimel, J. P., Palmer, R. G., Hernandez-Viezcas, J. A., Zhao, L., Gardea-Torresdey, J. L., Holden, P. A., 2012. Soybean susceptibility to manufactured nanomaterials with evidence for food quality and soil fertility interruption. Proc. Natl. Acad. Sci. U. S. A. 109, E2451-E2456.

Quik, J. T. K., Lynch, I., Hoecke, K. V., Miermans, C. J. H., Schamphelaere, K. A. C. D., Janssen, C. R., Dawson, K. A., Stuart, M. A. C., Meent, D. V. D., 2010. Effect of natural organic matter on cerium dioxide nanoparticles settling in model fresh water. Chemosphere 81, 711-715.

Read, D. S., Matzke, M., Gweon, H. S., Newbold, L. K., Heggelund, L., Ortiz, M. D., Lahive, E., Spurgeon, D., Svendsen, C., 2015. Soil pH effects on the interactions between dissolved zinc, nonnano- and nano-ZnO with soil bacterial communities. Environ. Sci. Pollut. Res. 23, 4120-4128.

Rico, C. M.; Morales, M. I.; Barrios, A. C.; McCreary, R.; Hong, J.; Lee, W.-Y.; Nunez, J.; PeraltaVidea, J. R.; Gardea-Torresdey, J. L., 2013. Effect of cerium oxide nanoparticles on the quality of rice (Oryza sativa L.) grains. J. Agric. Food Chem. 61, 11278-11285.

Rico, C.; Barrios, A.; Tan, W.; Rubenecia, R.; Lee, S.; Varela-Ramirez, A.; Peralta-Videa, J.; GardeaTorresdey, J., 2015. Physiological and biochemical response of soil-grown barley (Hordeum vulgare L.) to cerium oxide nanoparticles. Environ Sci \& Pollut Res. 22, 10551-10558.

Rittner, M. N., Abraham, T., 1998. Nanostructured materials: An overview and commercial analysis. JOM 50, 37-38.

Schwabe, F., Schulin, R., Limbach, L. K., Stark, W., Bürge, D., Nowack, B., 2013. Influence of two types of organic matter on interaction of $\mathrm{CeO} 2$ nanoparticles with plants in hydroponic culture.

Chemosphere 91, 512-520.

Schwabe, F., Tanner, S., Schulin, R., Rotzetter, A., Stark, W., von Quadt, A., Nowack, B., 2015. Dissolved cerium contributes to uptake of $\mathrm{Ce}$ in the presence of differently sized $\mathrm{CeO} 2$-nanoparticles by three crop plants. Metallomics 7, 466-477. 
Shyam, R., Aery, N. C., 2012. Effect of cerium on growth, dry matter production, biochemical constituents and enzymatic activities of cowpea plants [Vigna unguiculata (L.) Walp.]. J. Soil Sci. Plant Nutr. 12, 1-14.

Thomas, P. J., Carpenter D Fau - Boutin, C., Boutin C Fau - Allison, J. E., Allison, J. E., 2014. Rare earth elements (REEs): effects on germination and growth of selected crop and native plant species. Chemosphere 96, 57-66.

Taiz, L.; Zeiger, E., Plant Physiology, 2nd ed., Sinauer Associates, Inc., Publishers. Sunderland, Massachusetts, 1998.

US Environmental Protection Agency Washington D.C. DC, Test Methods for Evaluating Solid Waste. SW-846 Method 90811986.

Wang, Q., Ma, X., Zhang, W., Pei, H., Chen, Y., 2012. The impact of cerium oxide nanoparticles on tomato (Solanum lycopersicum L.) and its implications for food safety. Metallomics 4, 1105-1112.

Weiping, S., Fashui, H., Zhigang, W., Yuzhen, Z., Fugen, G., Hongoing, X., Mingliang, Y., Youhong, C., Mizhen, Z., Jiale, S., 2003. Effects of cerium on nitrogen metabolism of peach plantlet in vitro. Biol. Trace Elem. Res. 95, 259-268.

Yang, K., Lin, D., Xing, B., 2009. Interactions of Humic Acid with Nanosized Inorganic Oxides. Langmuir 25, 3571-3576.

Yuguan, Z., Min, Z., Luyang, L., Zhe, J., Chao, L., Sitao, Y., Yanmei, D., Na, L., Fashui, H., 2009. Effects of cerium on key enzymes of carbon assimilation of spinach under magnesium deficiency. Biol. Trace Elem. Res. 131, 154-164.

Zhang, P., Ma, Y., Zhang, Z., He, X., Zhang, J., Guo, Z., Tai, R., Zhao, Y., Chai, Z., 2012. Biotransformation of ceria nanoparticles in cucumber plants. ACS Nano 6, 9943-9950.

Zhang, W., Musante, C., White, J. C., Schwab, P., Wang, Q., Ebbs, S. D., Ma, X., 2016. Bioavailability of cerium oxide nanoparticles to Raphanus sativus L. in two soils. Plant Physiol. Biochem. http://dx.doi.org/10.1016/j.plaphy.2015.12.013

Zhang, Y., Chen, Y., Westerhoff, P., Crittenden, J., 2009. Impact of natural organic matter and divalent cations on the stability of aqueous nanoparticles. Water Research 43, 4249-4257.

Zhao, L., Peng, B., Hernandez-Viezcas, J. A., Rico, C., Sun, Y., Peralta-Videa, J. R., Tang, X., Niu, G., Jin, L., Varela-Ramirez, A., Zhang, J.-y., Gardea-Torresdey, J. L., 2012. Stress Response and Tolerance of Zea mays to CeO2 Nanoparticles: Cross Talk among H2O2, Heat Shock Protein, and Lipid Peroxidation. ACS Nano 6, 9615-9622.

Zhao, L., Peralta-Videa, J. R., Varela-Ramirez, A., Castillo-Michel, H., Li, C., Zhang, J., Aguilera, R. J., Keller, A. A., Gardea-Torresdey, J. L., 2012. Effect of surface coating and organic matter on the uptake of $\mathrm{CeO} 2 \mathrm{NPs}$ by corn plants grown in soil: Insight into the uptake mechanism. J. Hazard. Mater. 225-226, 131-138.

Zhao, L., Sun, Y., Hernandez-Viezcas, J. A., Servin, A. D., Hong, J., Niu, G., Peralta-Videa, J. R., Duarte-Gardea, M., Gardea-Torresdey, J. L., 2013. Influence of $\mathrm{CeO} 2$ and $\mathrm{ZnO}$ nanoparticles on cucumber physiological markers and bioaccumulation of $\mathrm{Ce}$ and $\mathrm{Zn}$ : a life cycle study. J. Agric. Food Chem. 61, 11945-11951. 
Zhao, L., Sun, Y., Hernandez-Viezcas, J. A., Hong, J., Majumdar, S., Niu, G., Duarte-Gardea, M., Peralta-Videa, J. R., Gardea-Torresdey, J. L., 2015. Monitoring the environmental effects of $\mathrm{CeO} 2$ and $\mathrm{ZnO}$ nanoparticles through the life cycle of corn (Zea mays) plants and in situ $\mu$-XRF mapping of nutrients in kernels. Environ. Sci. Technol. 49, 2921-2928. 


\section{Figure captions}

Figure 1. Concentration of cerium $(\mathrm{mg} / \mathrm{kg})$ in low organic matter soil (LOMS) and organic matter enriched soil (OMES) amended with $0-500 \mathrm{mg} / \mathrm{kg}$ nano- $\mathrm{CeO}_{2}$ before sowing kidney bean seeds. LOMS and OMES are sieved and refer to particles $\leq 2 \mathrm{~mm}$. OMES-OM refer to the sieved organic matter fraction $(>2 \mathrm{~mm})$ of the OMES. Values are expressed as mean $\pm \mathrm{SE}(n=4)$. Bars with different letters within same soil type, represent significant difference at $p \leq 0.05$.

Figure 2. Concentration of cerium $(\mathrm{mg} / \mathrm{kg})$ in three soil zones: surface, rhizosphere, and bottom zones of low organic matter soil (LOMS) and organic matter enriched soil (OMES) after 52 days of exposure to $0-500 \mathrm{mg} / \mathrm{kg}$ nano- $\mathrm{CeO}_{2}$ in presence of kidney bean plants. Values are expressed as mean $\pm \mathrm{SE}(n=4)$. No significant differences were observed at $p \leq 0.05$ between three zones in each soil treatment.

Figure 3. Cerium accumulation in kidney bean plant (A) roots, and (B) leaves, exposed to 0-500 $\mathrm{mg} / \mathrm{kg}$ nano- $\mathrm{CeO}_{2}$ in low organic matter soil (LOMS) and organic matter enriched soil (OMES). Values are expressed as mean $\pm \mathrm{SE}(n=4)$. Bars with different letters represent significant difference at $p \leq 0.05$ within a soil type.

Figure 4. (A) Photosynthetic pigment contents $(\mu \mathrm{g} / \mathrm{ml})$ in LOMS leaves, (B) Photosynthetic pigment contents $(\mu \mathrm{g} / \mathrm{ml})$ in OMES leaves of plants exposed to $0-500 \mathrm{mg} / \mathrm{kg}$ nano- $\mathrm{CeO}_{2}$. Values are expressed as mean $\pm \mathrm{SE}(n=4)$. Different letters represent significant difference at $p \leq 0.05$ within a soil type.

Figure 5. (A) Transpiraton rate $\left(\mathrm{mmol} \mathrm{m}^{-2} \mathrm{~s}^{-1}\right)$, (B) Stomatal conductance $\left(\mathrm{mmol} \mathrm{m}^{-2} \mathrm{~s}^{-1}\right)$, and (C) Net photosynthesis $\left(\mu \mathrm{mol} \mathrm{m} \mathrm{m}^{-2}\right)$ in leaves of plants grown in low organic matter soil (LOMS) and organic matter enriched soil (OMES) amended with $0-500 \mathrm{mg} / \mathrm{kg}$ nano- $\mathrm{CeO}_{2}$. Values are expressed as mean $\pm \mathrm{SE}(n=4)$. Bars with different letters represent significant difference at $p \leq$ 0.05 within a soil type. The symbol * represent significant interaction between soil and nano$\mathrm{CeO}_{2}$ exposure concentration at $p \leq 0.05$.

Figure 6. (A) Ascorbate peroxidase and (B) Catalase activity $\left(\mu \mathrm{mol} \mathrm{H}_{2} \mathrm{O}_{2}\right.$ degraded $\mathrm{min}^{-1} \mathrm{mg}^{-1}$ FW) in root, stems, and leaf tissues of plants grown in low organic matter soil (LOMS) and organic matter enriched soil (OMES) amended with $0-500 \mathrm{mg} / \mathrm{kg}$ nano- $\mathrm{CeO}_{2}$. Values are expressed as mean $\pm \mathrm{SE}(n=4)$. Bars with different letters represent significant difference at $p \leq$ 0.05 within a soil type. 


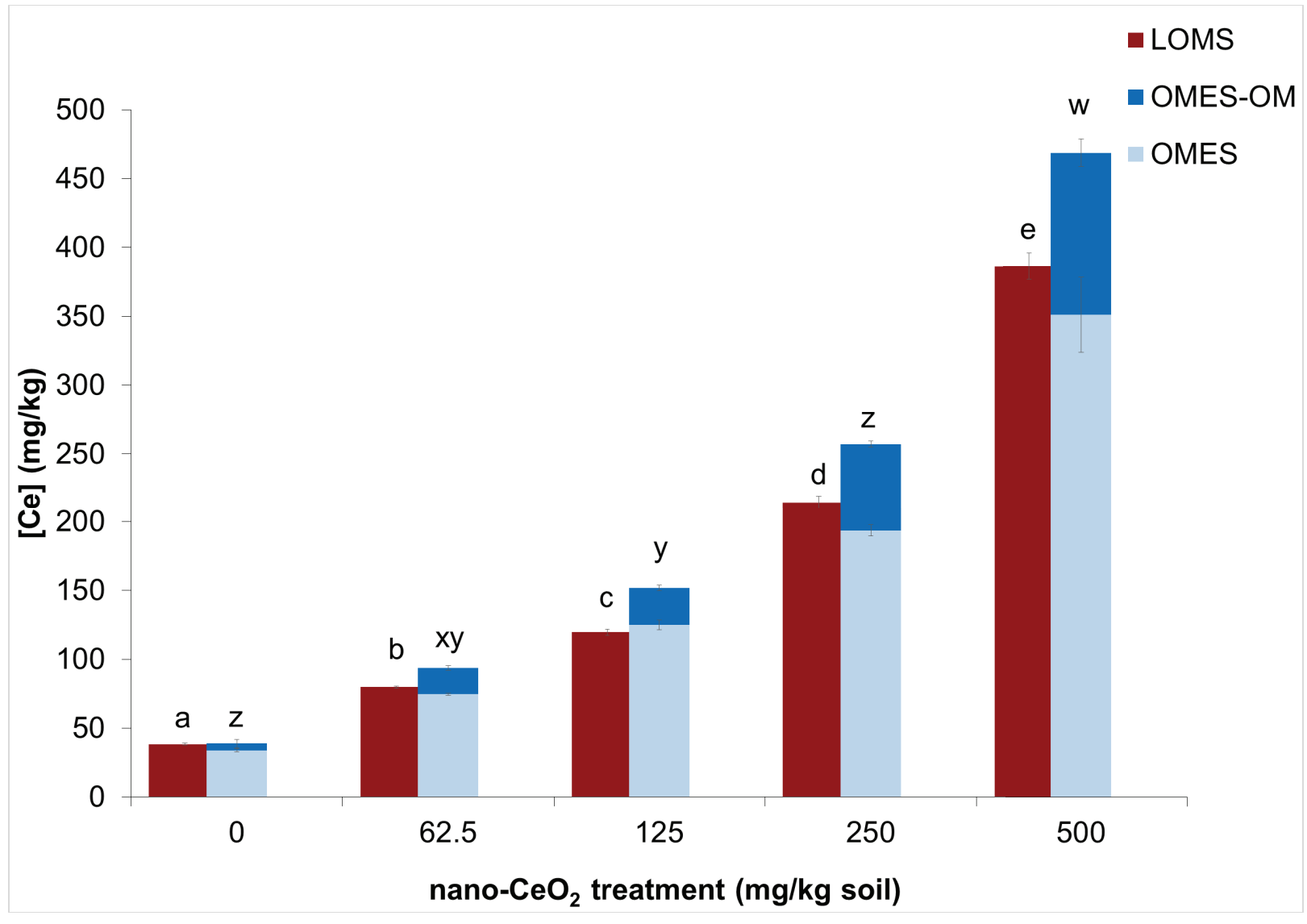

Figure 1. 


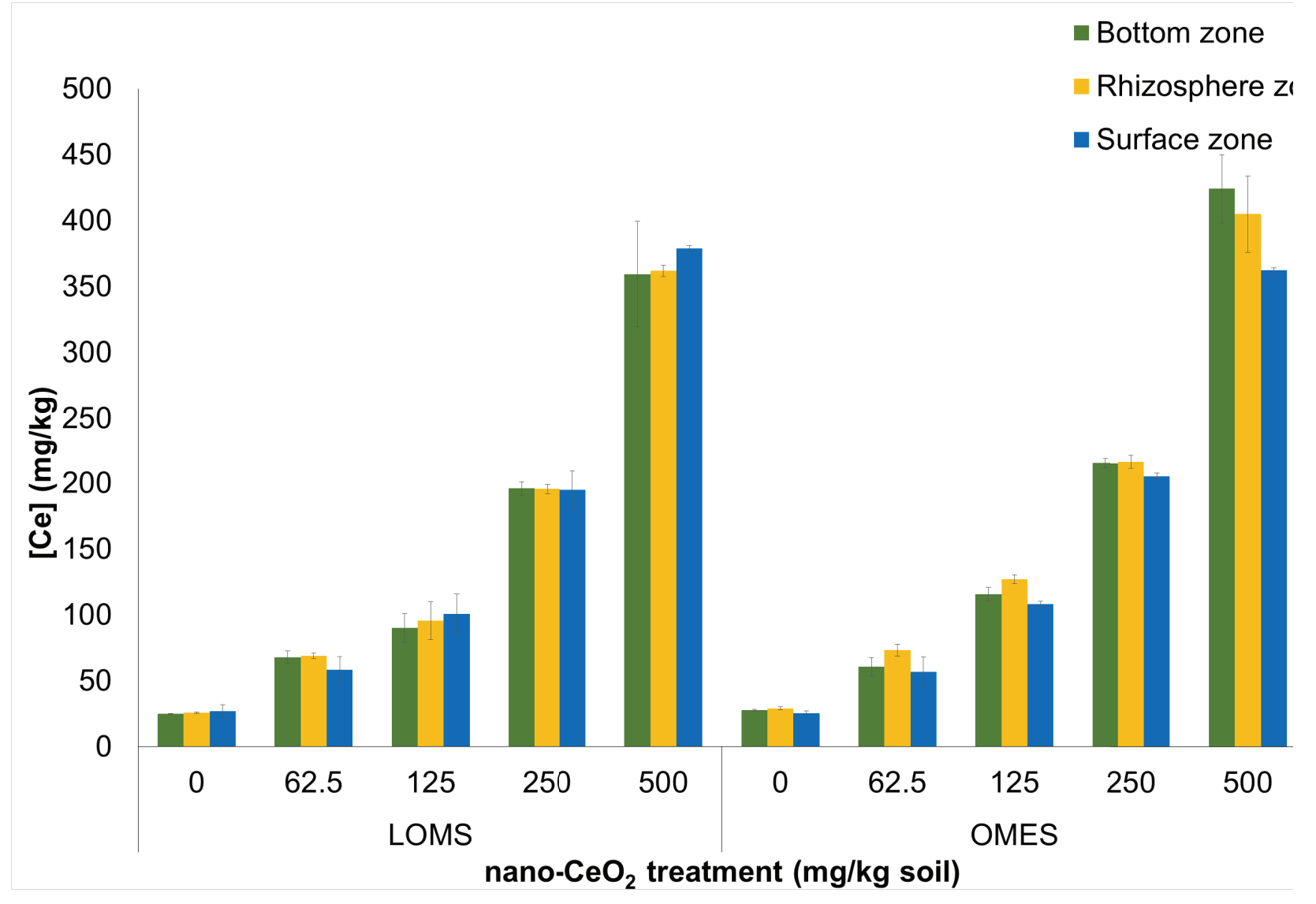

Figure 2. 


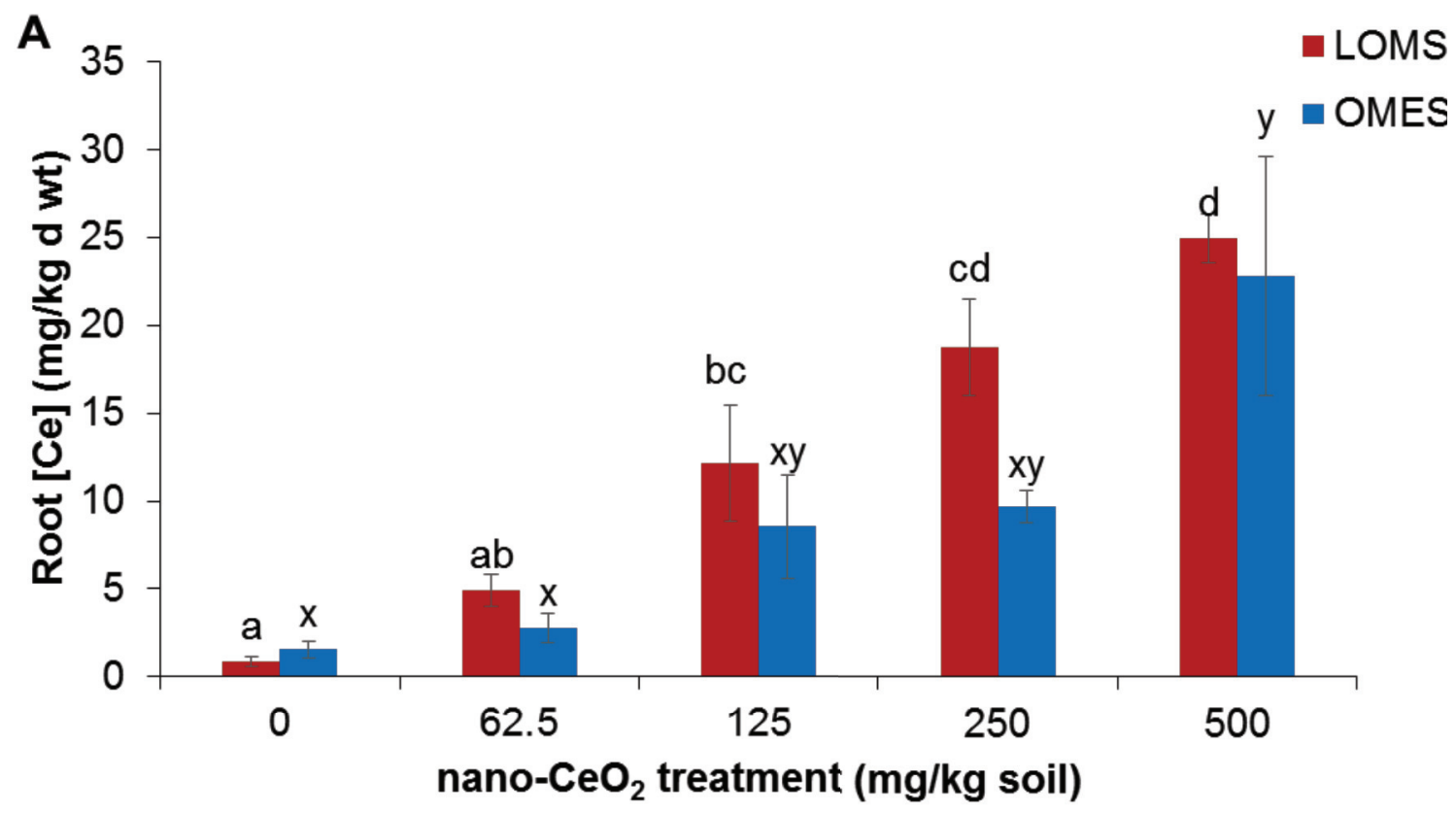

B

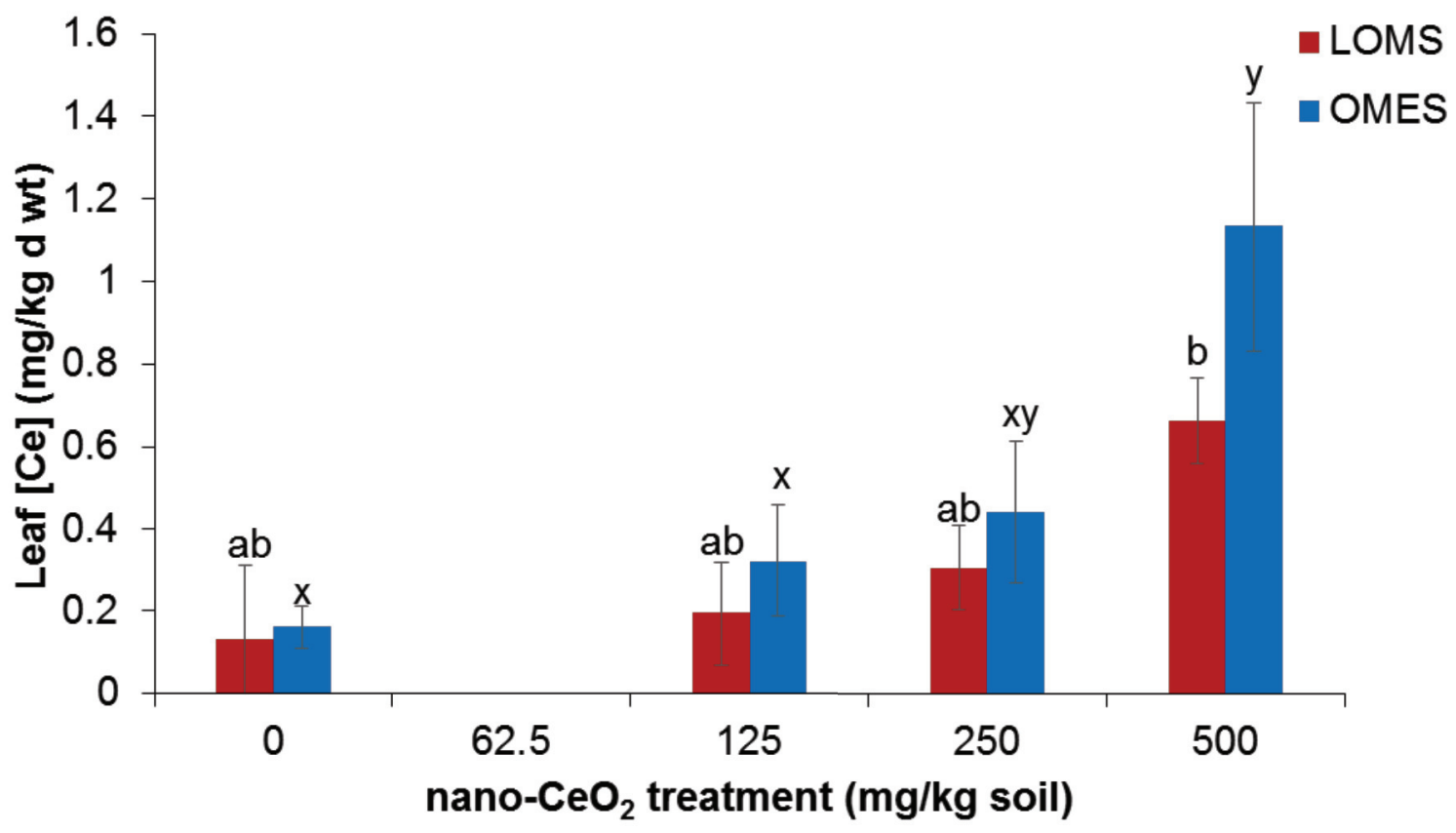

Figure 3. 

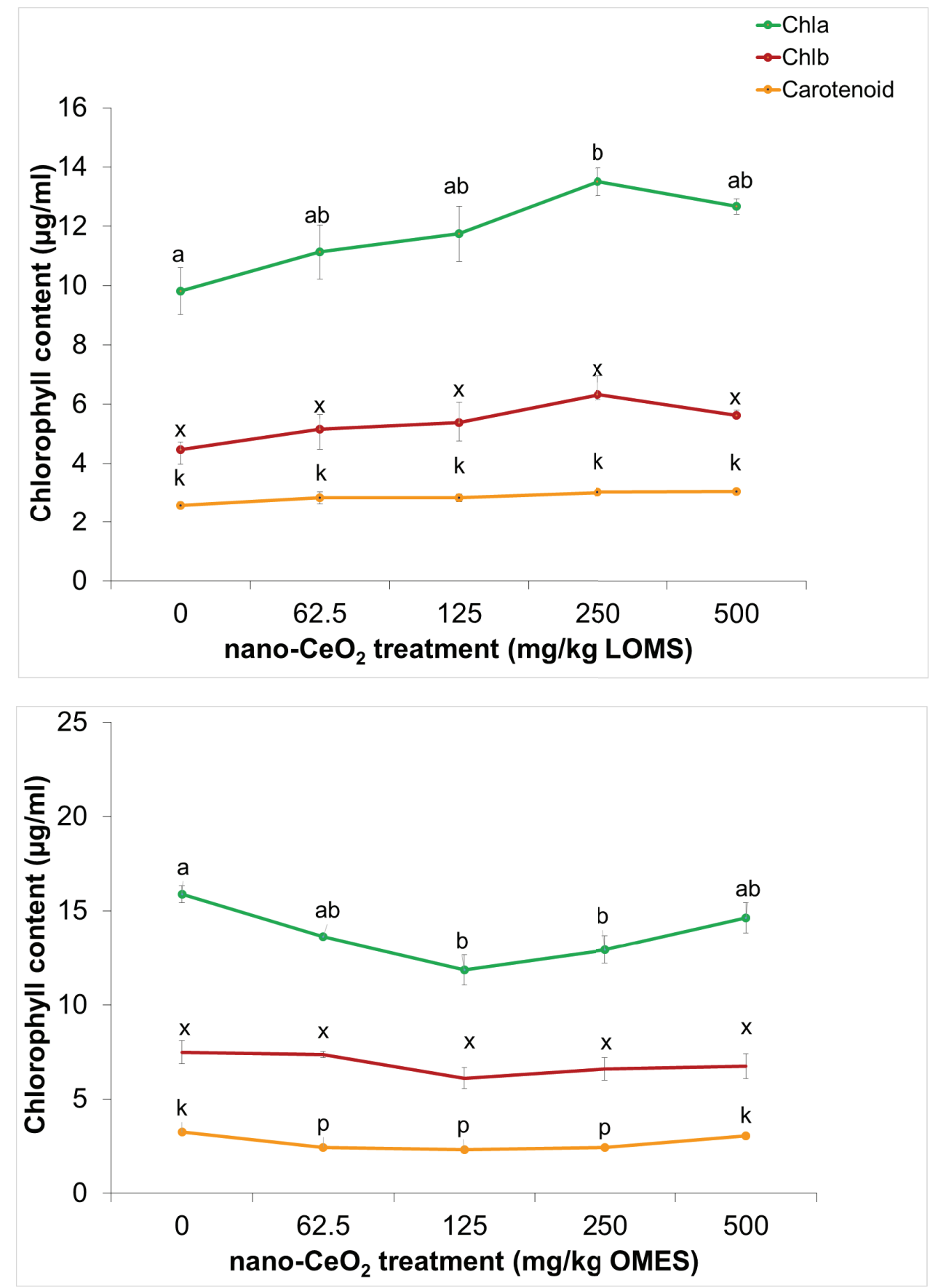

Figure 4. 

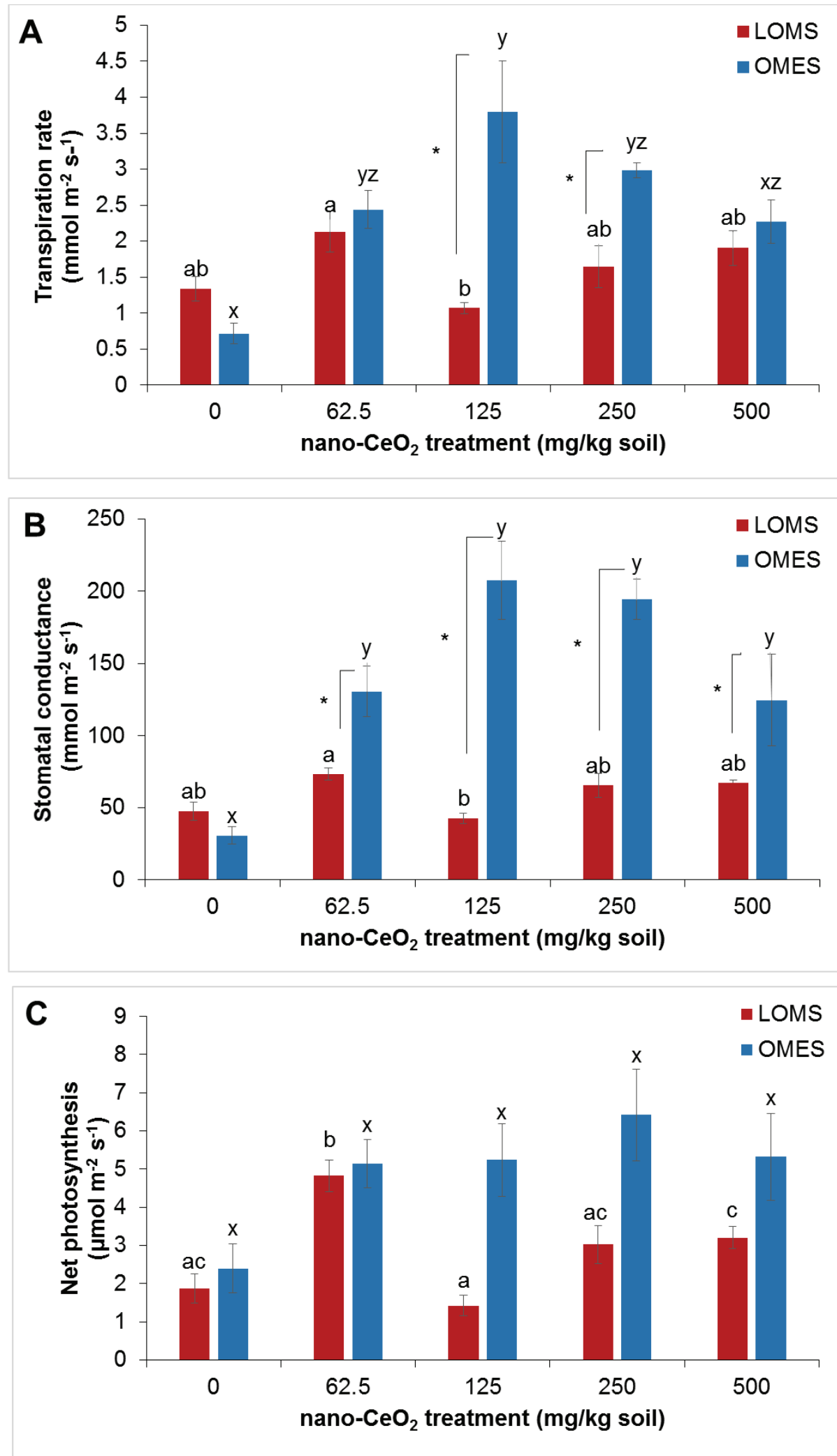

Figure 5. 
A

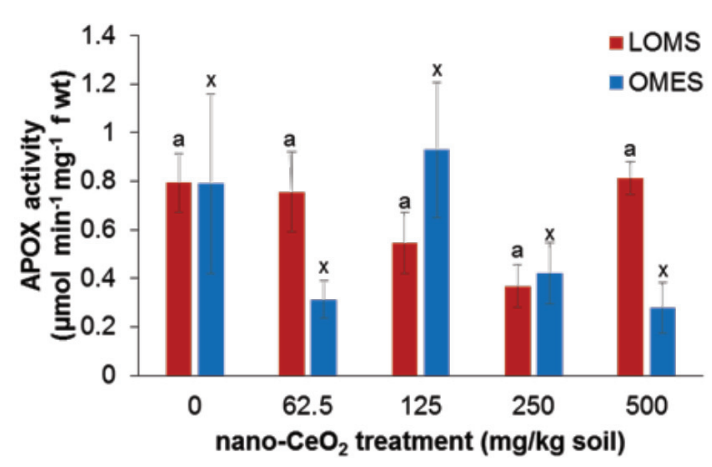

B

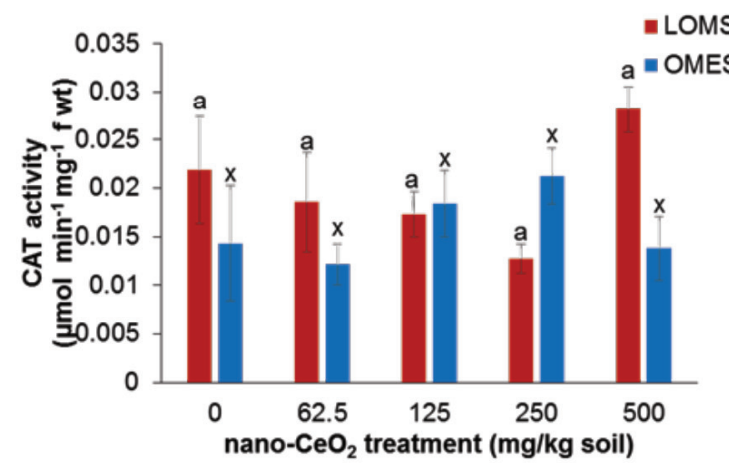

STEMS
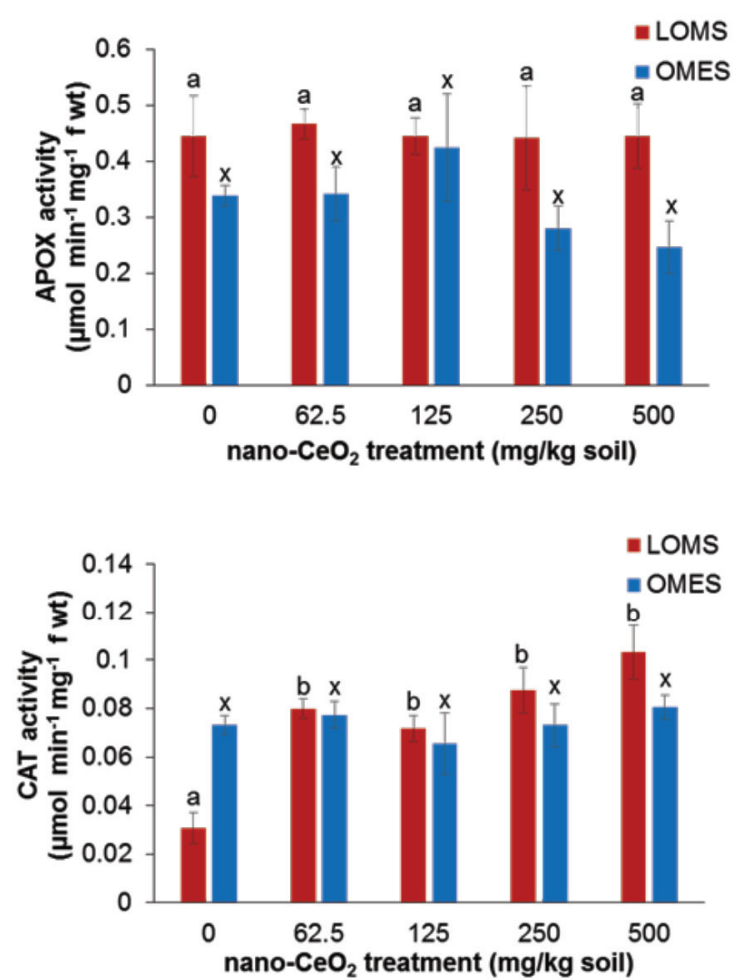

LEAVES
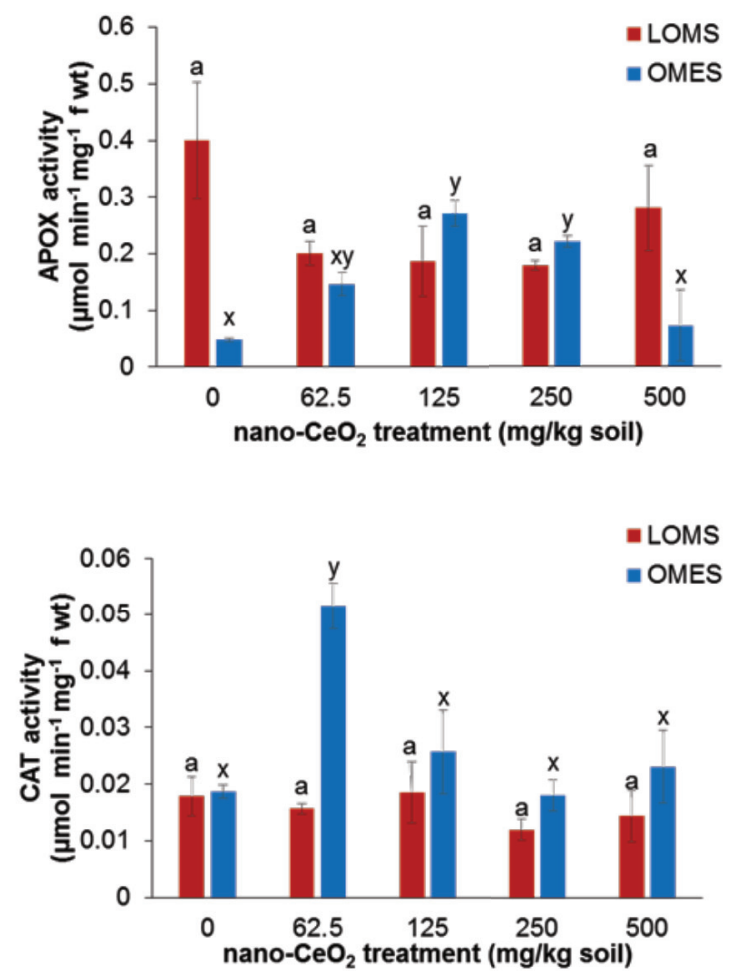

Figure 6. 
Table 1. Low organic matter soil (LOMS) and organic matter enriched soil (OMES) properties in response to 0-500 mg/kg nano$\mathrm{CeO}_{2}$.

\begin{tabular}{|c|c|c|c|c|c|c|c|c|c|c|}
\hline \multirow{2}{*}{$\begin{array}{l}\text { Soil } \\
\text { nano-CeO }{ }_{2} \text { treatment } \\
\text { (mg/kg soil) }\end{array}$} & \multicolumn{5}{|c|}{ Low organic matter soil (LOMS) } & \multicolumn{5}{|c|}{ Organic matter enriched soil (OMES) } \\
\hline & 0 & 62.5 & 125 & 250 & 500 & 0 & 62.5 & 125 & 250 & 500 \\
\hline Soil class & sandy loam & oil (64\% sand, & $31 \%$ silt, $5 \%$ & & & sandy loam & il (64\% sand, & $\%$ silt, $5 \%$ & & \\
\hline $\begin{array}{l}\text { Loss on ignition organic matter } \\
(\%)\end{array}$ & 4.2 & & & & & 10.1 & & & & \\
\hline Bulk density $\left(\mathrm{g} / \mathrm{cm}^{-3}\right)$ & 1.11 & & & & & 0.83 & & & & \\
\hline $\mathrm{pH}$ (water) & $\begin{array}{l}7.92 \pm \\
0.08 \mathrm{a}\end{array}$ & $\begin{array}{l}7.98 \pm \\
0.20 a\end{array}$ & $\begin{array}{l}7.88 \pm \\
0.05 a\end{array}$ & $\begin{array}{l}7.68 \pm \\
0.02 a\end{array}$ & $\begin{array}{l}7.95 \pm \\
0.03 a\end{array}$ & $\begin{array}{l}7.28 \pm \\
0.05 a\end{array}$ & $7.00 \pm 0.07 a$ & $\begin{array}{l}6.90 \pm \\
0.04 a\end{array}$ & $6.83 \pm 0.02 a$ & $\begin{array}{l}6.98 \pm \\
0.02 \mathrm{a}\end{array}$ \\
\hline $\mathrm{pH}\left(\mathrm{CaCl}_{2}\right)$ & $\begin{array}{l}7.53 \pm \\
0.05 a\end{array}$ & $\begin{array}{l}7.60 \pm \\
0.04 a\end{array}$ & $\begin{array}{l}7.68 \pm \\
0.02 a\end{array}$ & $\begin{array}{l}7.65 \pm \\
0.03 a\end{array}$ & $\begin{array}{l}7.70 \pm \\
0.00 \mathrm{a}\end{array}$ & $\begin{array}{l}7.05 \pm \\
0.03 a\end{array}$ & $7.03 \pm 0.05 a$ & $\begin{array}{l}6.93 \pm \\
0.02 a\end{array}$ & $7.13 \pm 0.05 a$ & $\begin{array}{l}6.98 \pm \\
0.03 a\end{array}$ \\
\hline Electrical conductivity & $\begin{array}{l}207.5 \pm \\
4.8 a\end{array}$ & $\begin{array}{l}395.0 \pm \\
60.8 b\end{array}$ & $\begin{array}{l}472.5 \pm \\
11.1 \mathrm{bc}\end{array}$ & $\begin{array}{l}545.0 \pm \\
38.6 c\end{array}$ & $\begin{array}{l}470.0 \pm \\
9.1 \mathrm{bc}\end{array}$ & $\begin{array}{l}485.0 \pm \\
35.7 a\end{array}$ & $\begin{array}{l}947.5 \pm \\
21.7 b\end{array}$ & $\begin{array}{l}992.5 \pm \\
19.7 b\end{array}$ & $\begin{array}{l}972.5 \pm \\
34.5 b\end{array}$ & $\begin{array}{l}982.5 \pm \\
32.2 b\end{array}$ \\
\hline Total dissolved solid & $\begin{array}{l}92.5 \pm \\
2.5 a\end{array}$ & $190 \pm 31.9 b$ & $\begin{array}{l}227.5 \pm \\
4.8 b\end{array}$ & $\begin{array}{l}262.5 \pm \\
18.9 b\end{array}$ & $\begin{array}{l}230.0 \pm \\
4.1 b\end{array}$ & $\begin{array}{l}240.0 \pm \\
19.2 \mathrm{a}\end{array}$ & $\begin{array}{l}470.0 \pm \\
10.8 b\end{array}$ & $\begin{array}{l}492.5 \pm \\
9.5 b\end{array}$ & $\begin{array}{l}482.5 \pm \\
17.0 \mathrm{~b}\end{array}$ & $\begin{array}{l}497.5 \pm \\
20.6 b\end{array}$ \\
\hline $\begin{array}{l}\text { Cation exchange capacity } \\
\text { (meq/100g)* } \\
\text { Macro-nutrients: }\end{array}$ & $\begin{array}{l}23.3 \pm \\
1.8 \mathrm{a}\end{array}$ & $21.6 \pm 1.5 a$ & $26.2 \pm 3.2 a$ & $\begin{array}{l}23.8 \pm \\
0.9 a\end{array}$ & $\begin{array}{l}22.4 \pm \\
1.0 a\end{array}$ & $\begin{array}{l}33.13 \pm \\
1.3 a\end{array}$ & $34.16 \pm 0.6 a$ & $\begin{array}{l}36.9 \pm \\
1.9 a\end{array}$ & $34.4 \pm 0.9 a$ & $\begin{array}{l}34.1 \pm \\
1.2 a\end{array}$ \\
\hline 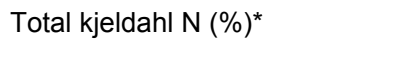 & $\begin{array}{l}0.06 \pm \\
0.002 a\end{array}$ & $\begin{array}{l}0.07 \pm \\
0.001 a\end{array}$ & $\begin{array}{l}0.07 \pm \\
0.001 a\end{array}$ & $\begin{array}{l}0.07 \pm \\
0.000 a\end{array}$ & $\begin{array}{l}0.07 \pm \\
0.002 a\end{array}$ & $\begin{array}{l}0.09 \pm \\
0.004 a\end{array}$ & $\begin{array}{l}0.10 \pm \\
0.002 a\end{array}$ & $\begin{array}{l}0.11 \pm \\
0.001 a\end{array}$ & $\begin{array}{l}0.11 \pm \\
0.001 a\end{array}$ & $\begin{array}{l}0.11 \pm \\
0.002 a\end{array}$ \\
\hline $\begin{array}{l}\text { Potassium (mg/kg) } \\
\text { Phosphorus (mg/kg) }\end{array}$ & $\begin{array}{l}4915 \pm \\
147 a \\
910 \pm 5.7 a\end{array}$ & $\begin{array}{l}4750 \pm \\
162 a \\
919 \pm 9 a b\end{array}$ & $\begin{array}{l}4720 \pm \\
162 a \\
908 \pm 8 a b\end{array}$ & $\begin{array}{l}5052 \pm \\
58 a \\
929 \pm 5 b\end{array}$ & $\begin{array}{l}4962 \pm \\
169 a \\
921 \pm 10 b\end{array}$ & $\begin{array}{l}5980 \pm \\
262 a b \\
846 \pm 30 a\end{array}$ & $\begin{array}{l}5864 \pm \\
130 a b \\
840 \pm 4 a\end{array}$ & $\begin{array}{l}6857 \pm \\
179 a \\
902 \pm 45 a\end{array}$ & $\begin{array}{l}5602 \pm \\
353 a b \\
788 \pm 32 a\end{array}$ & $\begin{array}{l}5284 \pm \\
159 b \\
789 \pm 39 a\end{array}$ \\
\hline Calcium (mg/kg) & $\begin{array}{l}28595 \pm \\
331 a\end{array}$ & $\begin{array}{l}28870 \pm \\
166 a\end{array}$ & $\begin{array}{l}28707 \pm \\
206 a\end{array}$ & $\begin{array}{l}26565 \pm \\
173 b\end{array}$ & $\begin{array}{l}26751 \pm \\
217 b\end{array}$ & $\begin{array}{l}27753 \pm \\
992 a\end{array}$ & $27509 \pm 95 a$ & $\begin{array}{l}28771 \pm \\
239 a\end{array}$ & $\begin{array}{l}26414 \pm \\
660 a\end{array}$ & $\begin{array}{l}25966 \pm \\
633 a\end{array}$ \\
\hline Magnesium $(\mathrm{mg} / \mathrm{kg})$ & $\begin{array}{l}6532 \pm \\
16 a\end{array}$ & $\begin{array}{l}6577 \pm \\
112 a\end{array}$ & $6519 \pm 60 a$ & $\begin{array}{l}5991 \pm \\
45 b\end{array}$ & $\begin{array}{l}6026 \pm \\
66 b\end{array}$ & $\begin{array}{l}6151 \pm \\
249 a b\end{array}$ & $6086 \pm 50 a b$ & $\begin{array}{l}6474 \pm \\
65 a\end{array}$ & $\begin{array}{l}5888 \pm \\
186 a b\end{array}$ & $\begin{array}{l}5663 \pm \\
119 b\end{array}$ \\
\hline $\begin{array}{l}\text { Sulfur }(\mathrm{mg} / \mathrm{kg})^{*} \\
\text { Micronutrients: }\end{array}$ & $706 \pm 25 a$ & $820 \pm 10 b$ & $828 \pm 24 b$ & $\begin{array}{l}764 \pm \\
14 a b\end{array}$ & $732 \pm 10 a$ & $779 \pm 42 a$ & $905 \pm 6 b$ & $958 \pm 19 b$ & $890 \pm 35 a b$ & $\begin{array}{l}863 \pm \\
18 a b\end{array}$ \\
\hline Aluminum (mg/kg) & $\begin{array}{l}21094 \pm \\
70 a\end{array}$ & $\begin{array}{l}20901 \pm \\
834 a\end{array}$ & $\begin{array}{l}20642 \pm \\
360 a\end{array}$ & $\begin{array}{l}20169 \pm \\
228 a\end{array}$ & $\begin{array}{l}20045 \\
\pm 387 a\end{array}$ & $\begin{array}{l}20887 \pm \\
783 a b\end{array}$ & $\begin{array}{l}21158 \pm \\
233 a b\end{array}$ & $\begin{array}{l}22962 \pm \\
348 a\end{array}$ & $\begin{array}{l}19509 \pm \\
1010 b\end{array}$ & $\begin{array}{l}18531 \pm \\
649 b\end{array}$ \\
\hline Copper (mg/kg) & $\begin{array}{l}24.3 \pm \\
0.2 a\end{array}$ & $23.5 \pm 0.1 \mathrm{~b}$ & $\begin{array}{l}23.7 \pm \\
0.2 \mathrm{ab}\end{array}$ & $14.0 \pm 0.1 \mathrm{c}$ & $13.8 \pm 0.2 \mathrm{c}$ & $24.4 \pm 1.4 a$ & $23.7 \pm 0.3 a$ & $\begin{array}{l}25.0 \pm \\
0.4 a\end{array}$ & $23.5 \pm 0.7 a$ & $\begin{array}{l}22.1 \pm \\
0.5 a\end{array}$ \\
\hline $\begin{array}{l}\text { Iron }(\mathrm{mg} / \mathrm{kg})^{*} \\
\text { Manganese }(\mathrm{mg} / \mathrm{kg})\end{array}$ & $\begin{array}{l}17371 \pm \\
89 a \\
342 \pm 4 a\end{array}$ & $\begin{array}{l}17434 \pm \\
220 a \\
362 \pm 6 a\end{array}$ & $\begin{array}{l}17453 \pm \\
128 a \\
342 \pm 4 a\end{array}$ & $\begin{array}{l}14370 \pm \\
90 b \\
312 \pm 1 a\end{array}$ & $\begin{array}{l}14457 \pm \\
139 b \\
332 \pm 3 a\end{array}$ & $\begin{array}{l}14329 \pm \\
453 a b \\
376 \pm 22 a b\end{array}$ & $\begin{array}{l}14203 \pm \\
122 a b \\
349 \pm 3 a b\end{array}$ & $\begin{array}{l}15063 \pm \\
162 a \\
369 \pm 5 a\end{array}$ & $\begin{array}{l}13768 \pm \\
326 a b \\
332 \pm 9 a b\end{array}$ & $\begin{array}{l}13388 \pm \\
255 b \\
324 \pm 8 b\end{array}$ \\
\hline Nickel (mg/kg) & $8.0 \pm 0.1 a$ & $7.6 \pm 0.1 \mathrm{a}$ & $7.9 \pm 0.1 a$ & $7.4 \pm 0.4 a$ & $7.6 \pm 0.3 a$ & $8.4 \pm 0.9 a$ & $6.9 \pm 0.3 a$ & $7.8 \pm 0.2 a$ & $6.8 \pm 0.7 a$ & $6.3 \pm 0.1 a$ \\
\hline Zinc (mg/kg) & $64.6 \pm$ & $64.4 \pm 3.0 \mathrm{a}$ & $60.9 \pm 2.3 a$ & $44.0 \pm$ & $43.7 \pm$ & $55.3 \pm 3.1 \mathrm{a}$ & $51.2 \pm 1.1 \mathrm{ab}$ & $54.4 \pm$ & $48.4 \pm 2.0 \mathrm{ab}$ & $46.2 \pm$ \\
\hline
\end{tabular}


4.1a

$0.3 \mathrm{~b}$

$0.7 \mathrm{~b}$

$0.9 a b$

Values are expressed as mean \pm SE $(n=4)$. The mean values with different alphabetical letters within each soil type denote significant difference at $p \leq 0.05$ detected by one-way ANOVA followed by post-hoc Tukey's test. Parameters with * represent significant difference between untreated LOMS and OMES detected by paired t-test (two-tailed). 


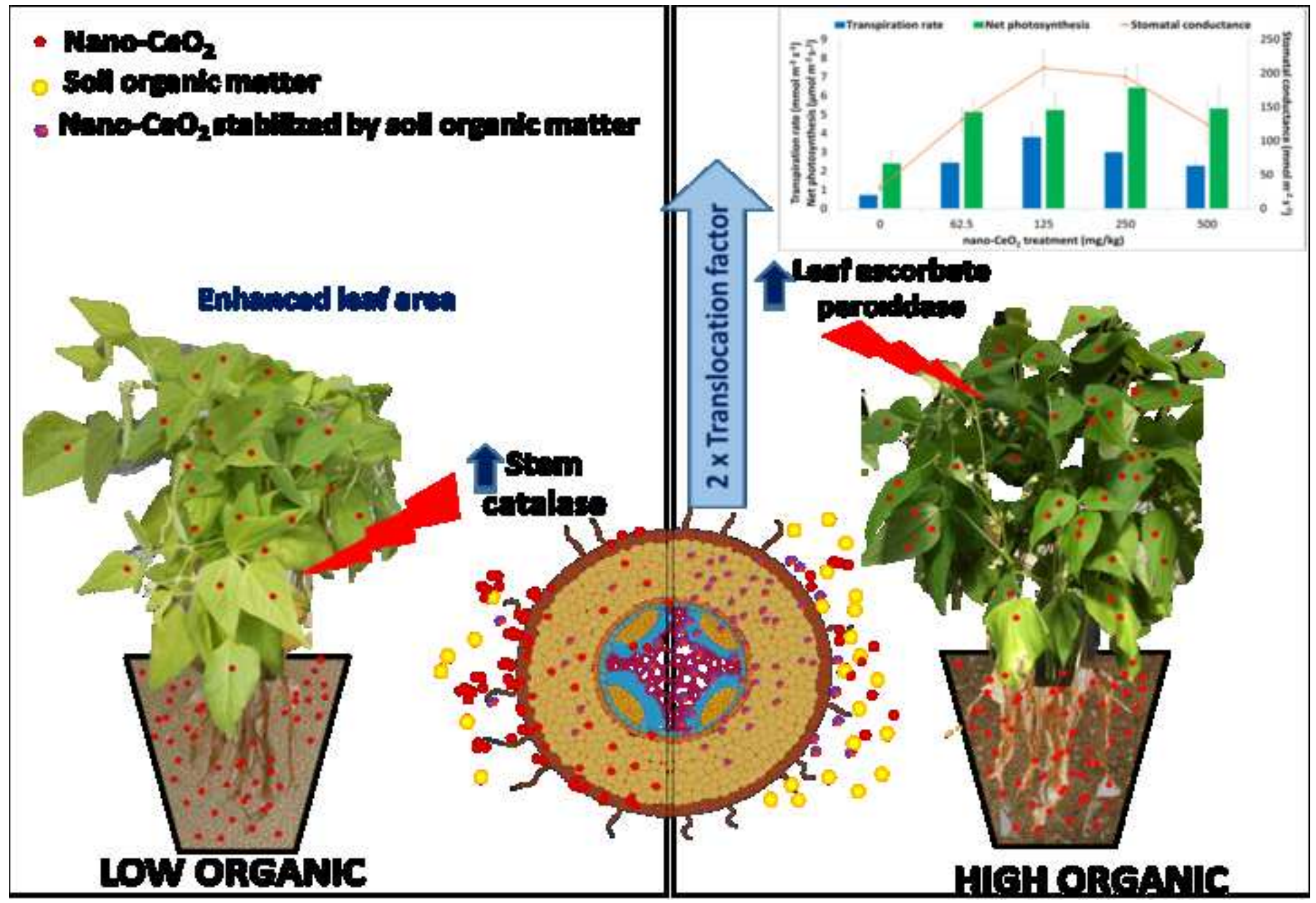

